Portland State University

PDXScholar

5-5-1993

\title{
The Complexities of Translation: Theories and Practicalities
}

Alice Ferguson

Portland State University

Follow this and additional works at: https://pdxscholar.library.pdx.edu/open_access_etds

Part of the French and Francophone Language and Literature Commons Let us know how access to this document benefits you.

\section{Recommended Citation}

Ferguson, Alice, "The Complexities of Translation: Theories and Practicalities" (1993). Dissertations and Theses. Paper 4663.

https://doi.org/10.15760/etd.6547

This Thesis is brought to you for free and open access. It has been accepted for inclusion in Dissertations and Theses by an authorized administrator of PDXScholar. Please contact us if we can make this document more accessible: pdxscholar@pdx.edu. 
AN ABSTRACT OF THE THESIS OF Alice Ferguson for the Master of Arts in Foreign Languages: French presented May 5, 1993.

Title: The Complexities of Translation: Theories and Practicalities

APPROVED BY MEMBERS OF THE THESIS COMMITTEE:

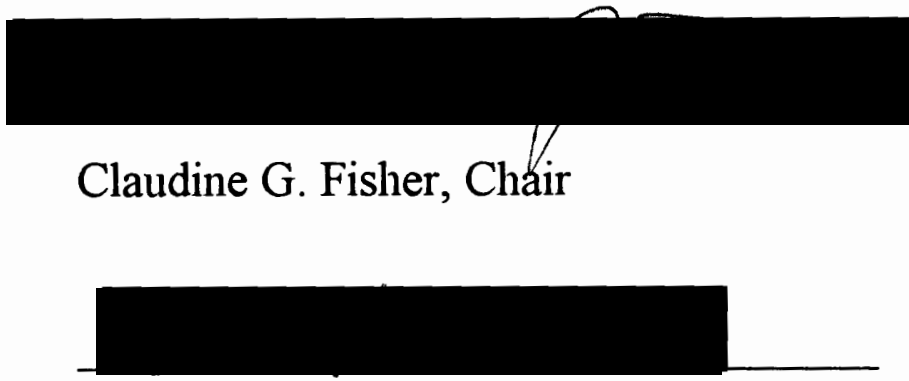

Eric Swenson

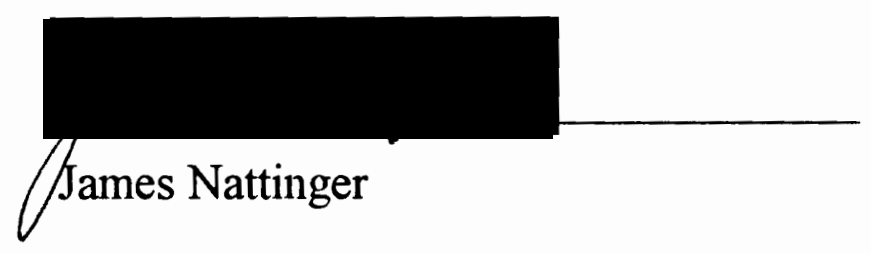

What are the difficulties involved in transferring a work of literature from one language to another, and what contributions might an analysis of the translation of a literary work make to the field of translation studies? These questions are explored in this thesis through the exploration of translation theories in general, and the analysis of one particular case with consideration of the theoretical implications it presents. The case study involves the comparison of the novel Gouverneurs de la rosée, written in 1944 by Haitian 
author Jacques Roumain, with Masters of the Dew, the translation by Mercer Cook and Langston Hughes which was published in 1947. This novel and its translation were chosen because of the additional layer of complexities presented by the original text's portrayal of the Haitian culture and the attempt by the translator to render it accessible to the target audience, which was America in the 1940's.

As an introduction, the importance and the complexities of translation are highlighted: an examination of the possibilities and shortcomings of machine translation provides ample evidence of both.

Chapter II outlines a brief history of the practice known as translation including its origins and evolution, as well as an overview of some of the controversy surrounding translation theory.

In Chapter III the lives and works of the author and translator, Jacques Roumain and Langston Hughes, are presented in order to show that, in spite of their significantly different cultures and upbringings, the two men developed similar political and social views. This gave each an especially keen understanding of the beauty and importance of the other's work, and thus a similar theoretical standpoint. It is shown that, for these reasons, Langston Hughes was exceptionally well qualified to translate the extraordinary work of Jacques Roumain.

Jacques Roumain's Gouverneurs de la rosée is a principal work of Haitian literature in that - in words and spirit - it embodies the Haitian experience. For this reason, it provides an especially interesting subject for the study of translation. In order to better appreciate the scope of the task undertaken by Hughes and Cook, an overview of the origins and features of Gouverneurs de la rosée is presented in Chapter IV: the plot, images and 
messages of the novel are outlined, and the techniques used by Roumain to create its distinctly Haitian "flavor" are highlighted. The social significance of the work is considered, an appreciation of which is essential to accurately assess the success of its translation.

Chapters V and VI examine the similarities and dissimilarities between Roumain's novel and Hughes' and Cook's translation. In Chapter V, the emphasis is on the form and structure of the texts (i.e. narrative style, syntax, foreign words, etc.), whereas in Chapter VI, the focus is on poetic language (i.e. metaphors, alliterations, and rhythms). In both chapters, the effects of the choices made by the translators are analyzed.

Finally, conclusions are drawn regarding the lessons to be learned from this case in particular which might be applied to the art of translation in general. 
THE COMPLEXITIES OF TRANSLATION:

THEORIES AND PRACTICALITIES

by

ALICE FERGUSON

A thesis submitted in partial fulfillment of the requirements for the degree of

\author{
MASTER OF ARTS \\ in \\ FOREIGN LANGUAGES: FRENCH
}

Portland State University

1993 


\section{TO THE OFFICE OF GRADUATE STUDIES:}

The members of the Committee approve the thesis of Alice Ferguson presented May 5, 1993.

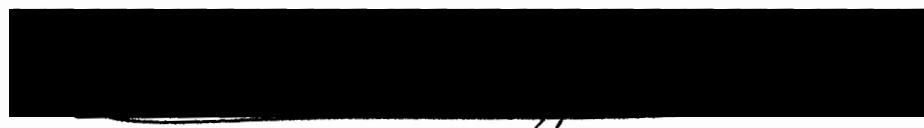

Claudine G. Fisher, Chøir

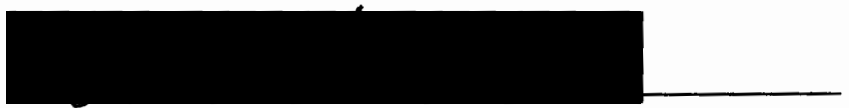

Eric Swenson

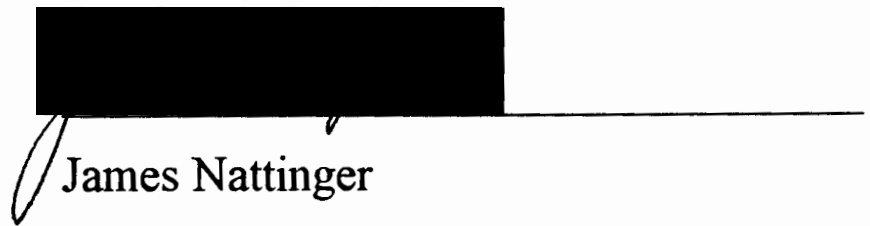

APPROVED:

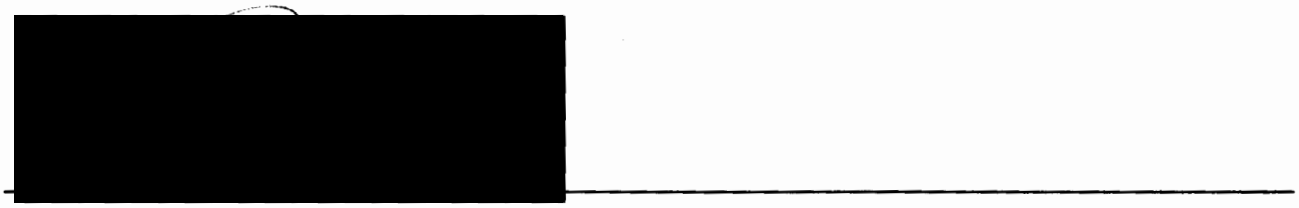

Linda Parshall, Chair, Department of Foreign Languages and Literatures

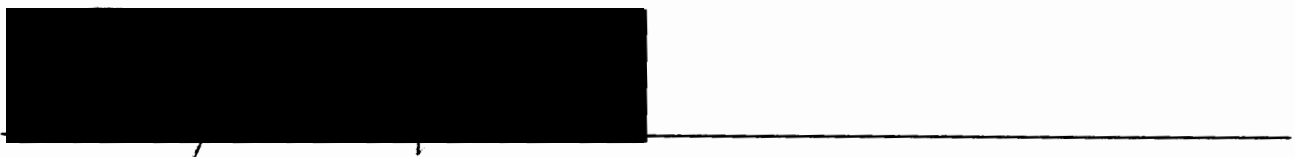

Roy W. Koch, Vice Provost for Graduate Studies and Research 


\section{ACKNOWLEDGMENTS}

I would like to thank my friends and professors of French at Portland State University - in particular: Claudine Fisher, Françoise Paheau, and Suzanne Detlefsen - for their inspiration and encouragement.

I would especially like to thank my parents and Glen, without whose love and support I would not have begun or finished this project. 


\section{TABLE OF CONTENTS}

PAGE

ACKNOWLEDGMENTS

iii

CHAPTER

I INTRODUCTION

The Power of Translation

II THE HISTORY OF TRANSLATION AND

EVOLUTION OF TRANSLATION THEORY

9

From the Rosetta Stone to Machine Translation .............. 9

Translation: Art or Science? ....................................... 14

III MISE EN SCENE: THE AUTHOR AND THE

TRANSLATOR

22

Jacques Roumain $(1907$ - 1945) ................................... 22

Langston Hughes (1902 - 1967) .................................... 27

"Shared Vision" ....................................................... 30

IV GOUVERNEURS DE LA ROSEE …….......................... 36

Origins of Roumain's Text ......................................... 36

Features of Roumain's Text ....................................... 41

$\mathrm{V}$ MASTERS OF THE DEW: STRUCTURAL ASPECTS ... 46

Features of Hughes' Text ............................................. 47

VI MASTERS OF THE DEW: POETIC LANGUAGE .......... 63

Features of Hughes' Text ............................................ 63 
VII CONCLUSION . 


\section{CHAPTER I}

\section{INTRODUCTION}

\section{THE POWER OF TRANSLATION}

In our ever-shrinking world, continual advances in technology are making travel and communication simpler, faster and more accessible, and contact between countries and cultures is continually increasing. With this contact, the role of translation is ever-growing as we attempt to share art, information and ideas.

In the realm of science and technology, many look to computers as a possible means of increasing the volume, speed and accuracy of translation for the enormous quantity of scientific findings, technical manuals, etc. which need to be made available in a wide variety of languages. Bar-Hillel cites the "urgency of having foreign language publications, mainly in the fields of science, finance, diplomacy, translated with high accuracy and reasonable speed [sic]" and, as long ago as 1964, pointed to the "scarcity of expert bilinguals [which] is causing a $\log$ jam in scientific translation... costing research... millions of dollars yearly" (154). The possibilities of machine translation were first investigated in 1945 when the computer was still brand new, and a great deal of research and development has been committed to the quest for effective machine translation over the last five decades. 
In a recent article, Barry Hillenbrand considers the Japanese's aggressive efforts to develop effective translation by computer, as well as the prospects of these machines for the future. As the reason for Japan's urgency in developing this technology, Hillenbrand points to their "strong thirst for information from other nations and a growing need to disseminate their documents around the world" (26). Toshiba has created a program named AS-TRANSAC which manages to translate "simple English into serviceable, if stilted Japanese" (Hillenbrand, 26), as does Fujitsu's Atlas program. In 1989, IBM Japan translated four IBM manuals from English into Japanese using their SHALT computer; their goal was to complete from twenty to thirty manuals in 1990, and they anticipate that by 1995 , the vast majority of the translation work done in their internal publications department will be done by machines (Hillenbrand, 26).

The process involved in translation by machine appears quite straightforward: (1) the computer analyzes the syntax of the source sentence to determine its grammatical structure and parts of speech; (2) the words of the sentence are translated using a bilingual dictionary; (3) the output is rearranged into a logical order according to the syntactical rules of the target language and the computer's stored "understanding" of the original sentence's meaning from step one. Attempts to improve this basic process have included (1) rearranging the syntax of the source language sentence into that of the target language before the translation process begins, and (2) the development by some programmers of an interlingual "hub" language - a coded computer language into and from which each language can be transferred. The latter avoids the necessity of programming separate bilingual dictionaries and 
comparative syntactical analyses for each pair of source and target languages used (Hillenbrand, 26).

Regardless of these efforts to simplify the steps of the process, however, one need only consider the number of possible options that a bilingual dictionary might offer for any one particular source term and wonder what procedure the computer will use to select the most appropriate in order to appreciate the fundamental complexity of the operation. Nagao gives an example of the potential difficulty that a computer may have in interpreting even the simplest of sentences. The statement "Time flies like an arrow" is quickly and easily understood by any reader of English familiar with similes. For a computer, however, which is programmed only to "understand" some logical meaning for a group of words, a second, less obvious message is possible. "Flies" is the third person singular of the verb "to fly," but it can also be the plural of the noun "fly." Likewise, "like" is not only a conjunction, but also the third person plural form of the verb "to like." Given these alternate meanings, the message of the sentence could be that these "hypothetical 'time flies' are fond of a particular arrow!" (23-24). It is obvious that if the language of the document to be translated is not entirely concrete and factual, the computer will no doubt fail, for - in spite of the tremendous advances in computer technology, artificial intelligence and cybernetics in the last decade, we are still far from being able to program an understanding of metaphor or satire, for example. Indeed, no computer is capable of translating even the most straightforward and technical of texts entirely without error "without the aid of a bilingual editor who can fine-tune the output for ambiguities in the vocabulary, to say nothing of shades of meaning" (Hillenbrand, 26). 
Overall, the conclusion remains that, while computers may prove quite useful in reducing a great deal of the repetitive and basic work involved in the translation of technical texts, a human being's input in the form of editing for syntactical accuracy and choice of words will always be required for even the most basic of writing styles. Furthermore, the trend in manual-writing is to move away from dry, technical language and toward a more casual, "userfriendly" prose as technology - computers in particular - is becoming accessible to more and more non technical users (cf. the popular PCs for Dummies by Gookin \& Rathbone, 1992). Because this more casual prose is certain to include more slang, idioms, puns, etc., human involvement in translation by machine will, by necessity, increase rather than decrease.

This very modern problem of how to create a machine that can translate effectively emphasizes the ancient problem of translation in general: differences in experience and world view which are reflected in the languages of different cultures make perfect translation impossible. This by no means suggests that translation attempts are futile. On the contrary, there is no question as to the crucial role of translations over the centuries. Consider, for example, the number of texts that are more widely read in translated form than in their language of origin - from Homer's Iliad to Freud's Interpretation of Dreams. The translations are read as though they are the original work, and were the texts available only in the original Greek and German respectively, they would not be accessible to nearly the audience that they are.

It is obvious that translation can greatly influence the popularity and success of an author: the work of Edgar Allan Poe, for example, would not enjoy the success that it does in France were it not for the translations of 
Beaudelaire. It is interesting to note as well that, as in the previous example, "good" translations, those that have become successful works in their own right, are not necessarily the most "faithful": were Beaudelaire's translations of Poe to be re-translated into English, the result would not be the original work. Similarly, the popular "Arabian Nights," the collection of Arabic stories written between the fourteenth and sixteenth centuries, was "introduced into Europe through Antoine Galland's French translation (170417)" (Betts). It was this translation, entitled "Mille et Une Nuits," which served as the basis for all subsequent Western interpretations, including the "best-known English version (1885-88)... by the explorer Sir Richard Burton," (Betts). Another example of this case is the popular "Mother Goose" nursery rhymes. The original text, "Contes de ma mère l'Oye," was written in 1697 by the French poet and critic Charles Perrault. The first English translation of his stories appeared in 1729 and, in 1760, "a collection of nursery rhymes, based on French and English sources, appeared in London... under the name of Mother Goose's Melodies" ("Mother Goose"). The British translations and adaptations were the basis for the widely popular American versions which have undoubtedly "strayed" significantly from the text of origin.

Examples such as these are analogous to the "hub" language system used in translation by computer. These examples suggest how this system may be problematic insofar as it presents the potential for erroneous word choice on two fronts: if there is an ambiguous wording, the computer's interpretation, "hub" language word choice and subsequent target language word choice may all stray progressively from the originally intended meaning. 
Indeed, the reason that there exist so many different translations of so many great works of literature - and the reason that they will continue to be translated - is that "Words, and ideas, mean different things to different people, even within the framework of the same language" (Forster, 1-2), and therefore a translation presents one interpretation and rendition of the original text. As Hodges explains: "The successful translator must somehow skillfully yet judiciously alter literal meaning to capture the spirit of the text. In this sense he provides an interpretation of the original..." (vii). It is safe to suggest that there are as many different interpretations of any given work of literature as there are readers, and, therefore, never one "exact" translation.

Given the impact that a translation can have on both the source and target cultures and the impossibility of somehow producing a "true," an "identical" work, is it even realistic to undertake translations of literary work? Does a translator in fact do a disservice to the original text and culture by "rewriting" it? Lefevere responds that if a text is not either translated or critiqued and thus made available to a large reading public, it could lead to the work's demise:

If a work of literature is not rewritten in one way or another, it is not likely to survive its date of publication by many years or even many months. It is also a fact of literary life in our day that works of literature not rewritten in either English or Russian do not stand a great chance of being included in any canon of world literature, no matter how high their intrinsic value as literature may be rated. (14)

Indeed, making the literature of a culture available to a wider reading public through translation can greatly impact its success. 
In recent years there has been a growing interest in the many different cultures within and outside our borders - the literature of which had widely been considered "marginal" and therefore somehow not of value. Translation plays a critical role in making the literature of all cultures accessible to the general public, therefore heightening awareness, acceptance and appreciation. Lefevere asserts that translation - like other forms of "rewriting" such as criticism - "exerts an enormous influence not only on the image one literature is given of another but also on the image members of a culture are given of their own and other literatures" (14).

Outside the field of translation, many may well assume that anyone who is proficient in at least two languages can be a translator: the process involves simply finding equivalencies in the target language for the original text, and where the translator has strayed from the meaning of the original text, he or she has erred. Having struggled with the plethora of choices involved in what had appeared at the outset to be the simplest of translation projects - that is, fairly "dry," technical texts written in a very straightforward language containing little if any "color" in the way of idioms, metaphors, or other poetic tropes - I have come to appreciate the complexities inherent in the act of translation regardless of the translator's language skills. I have wondered what light might be shed on the nature of these complexities through the comparison of an original text and its widely accepted, "good" translation. An interesting exercise would be to: 1) find an author and translator who share important political, religious and social beliefs, 2) examine the dissimilarities between their corresponding works, and 3) try to understand why even the most "qualified" translator chooses solutions which may appear "unfaithful" to the original text. To this end, I will consider 
excerpts from the novel Gouverneurs de la rosée by Haitian author Jacques Roumain and the translation of this original work, Masters of the Dew, ${ }^{*}$ by Mercer Cook and Langston Hughes, and present examples of some of the translation's successes and failures which underscore some of the difficulties inherent in the translation of literature.

*I will, for simplicity's sake, refer to this text as Hughes' translation, not because I underestimate the contribution that was made by Cook, but rather because the final decisions regarding word choice, additions, omissions, etc. were undoubtedly the responsibility of Hughes. 
CHAPTER II

\section{THE HISTORY OF TRANSLATION AND EVOLUTION OF TRANSLATION THEORY}

\section{FROM THE ROSETTA STONE TO MACHINE TRANSLATION}

For as long as there have existed different languages, translation has been both necessary and a source of great controversy. There is evidence of translation activity as early as the third millennium $\mathrm{BC}$ : Babylon was a polyglot city, and Sargon of Assyria "delighted in having his exploits proclaimed with elaborate embellishments in the many languages of his empire" (Nida, 11). The translation of Sumerian, the oldest written language of Mesopotamia which began its evolution from a pictographic to its cuneiform writing system circa $3100 \mathrm{BC}$ (Greppen), was spearheaded by the work of Sir Henry Creswick Rawlinson in the nineteenth century. His work "led to the eventual decipherment of Babylonian cuneiforms, thereby greatly extending knowledge of ancient Near Eastern and biblical history" (Fielden). Work continues today on the translation of the tens of thousands of clay tablets housed in the Neo-Assyrian library of Ashurbanipal which dates from the seventh century BC. The tablets of this library, rediscovered in 1850 by A. H. Layard, contain inscriptions which include information ranging from astronomical data to narrative poems (Jones). Finally, the discovery in 1799 
of the Rosetta Stone and its key to deciphering Egyptian hieroglyphics established the existence of translation in the second century BC.

As for the evaluation of translations, historically the emphasis has been on the quality of the finished product as opposed to a consideration of the process of translation itself (House, 4). Considerations of translation practices stemmed from the critique of Bible translations. Jerome, commissioned by Pope Damascus in $384 \mathrm{AD}$. to translate the New Testament, stressed the need to translate "sense for sense and not word for word." He found a definition of the translator's "bind" in Cicero:

...it is hard to preserve in a translation the charm of expressions which in another language are most felicitous... If I render word for word, the result will sound uncouth, and if compelled by necessity I alter anything in the order or wording, I shall seem to have departed from the function of a translator (in Nida, 13).

The controversy surrounding the translation of this most important text is alive and well today: the Dead Sea Scrolls, discovered in the late 1940's, were dated from the second century $\mathrm{BC}$ through the first century $\mathrm{AD}$ and believed to "...give firsthand evidence for Jewish thought and religion in the New Testament period" (Saldarini). The original text of the scrolls has largely been kept shrouded in secrecy by the clique of scholars who have been studying, interpreting and translating them for the last forty years. Following the "leaking" of one section of the documents, however, the accuracy of the translation as well as the dating of the scrolls has been called into question. Not only was the Hebrew name Yeshua (Jesus) mistranslated as Joshua (Yehosuah) thus refuting the pre-Jesus dating of the scrolls, but 
recent scientific findings have called into question the accuracy of the carbon14 dating method used to support the $300 \mathrm{BC}-50 \mathrm{AD}$ date of origin theory (Altman). Altman suggests that "some scholars who are anti-semitic or antitheistic have controlled access to them [the Dead Sea Scrolls] as a springboard to promote their theories of Biblical criticism that the books of the Old and New Testaments were written long after many of the events they describe" (C6).

During the Middle Ages in Western Europe, the majority of translation involved that of religious essays into "stiff, ecclesiastical Latin," and during the Renaissance, due to the "rediscovery of the ancient world," many texts were being translated from Greek - apparently with less attention and care than was afforded the translation of religious texts: Flora Ross Amos remarked that, "In contrast to translators of secular works, Bible translators labored long and carefully" (in Nida, 14). Antoine Berman considers the surge in the number of translations which appeared in the sixteenth century due in particular, he suggests, to the growing acceptance of a wider variety of texts as being "worthy" of translation: "A la Renaissance, le champ du traduisible devient illimité: n'importe quel texte, de n'importe quel genre, de n'importe quelle langue, est désormais considéré comme bon à traduire" (24) and, for nearly the entire century, the translation of a text was considered as valid as the original: "le traduit fait autorité" (24). Berman concludes that it was during this period that for the first time in the West, translating became "une activité manifeste et définie," evidence for which is seen in the emergence of a specific term defining the act of translating (traduction), as well as the "multiplication d'écrits sur la traduction" (26) - translation itself was becoming a topic worthy of consideration and study. 
In his overview of the history of translation theory, Nida emphasizes the remarkable impact made by Martin Luther, in particular with his appreciation for the target audience's reception and understanding of the translated work. With his translation of the New Testament which appeared in 1522 he demonstrated the "importance of full intelligibility," and he acknowledged that this may be obtained at the expense of complete accuracy. He presented as acceptable solutions to translation dilemmas: "(1) shifts in word order;... (2) suppression of Greek or Hebrew terms which had no acceptable equivalent in German;... (3) use of phrases where necessary to translate single words in the original;... (4) shifts of metaphors to non metaphors and vice versa;... and ... (5) careful attention to exegetical accuracy and textual variants" (in Nida, 14-15).

Nida credits a Frenchman, however, with having been the first to formulate a theory of translation. In 1540, Étienne Dolet published a "statement of translation principles" which were as follows: "1) The translator must understand perfectly the content and intention of the author whom he is translating. 2) The translator should have a perfect knowledge of the language from which he is translating and an equally excellent knowledge of the language into which he is translating" (in Nida, 15-16).

Georges Mounin has dubbed the seventeenth and eighteenth centuries the age of "Les Belles Infidèles" because of the apparently "unrestrained freedom" exercised by the translators of secular works (Nida, 17). For example, Abraham Cowley defended the liberties he took in translating Pindar's Odes when he wrote in 1656: "If a man should undertake to translate Pindar word for word, it would be thought one Mad-man had translated another... I have... left out and added what I please; nor made it so much my 
aim to let the reader know precisely what he spoke, as what was his way and manner of speaking" (in Nida, 17). Others such as Dryden, however, strongly opposed Cowley's style and called his translations "imitations... in which the translator assumes the liberty not only to vary the words and sense, but also to leave both if the spirit of the original seems to require," as opposed to the two other types of translations that he specified: "metaphrase... a word-forword and line-for-line type of rendering," and "periphrase... a translation in which the author's work is kept carefully in view, but in which the sense rather than the words are followed" (in Nida, 17-18). Dryden asserted: "Imitation and verbal version [metaphrase] are in my opinion the two extremes, which ought to be avoided," and of which paraphrase, he implies, represents the happy medium (in Nida, 18).

Nida cites Matthew Arnold as a proponent of a more literal tendency in translation: he translated Greek classics for a select audience, namely those who were familiar with, able to read, and could therefore refer to the original works. When translating for a broader audience, however, such a "literalistic view of translation" can have "pernicious effects" according to Nida, and he submits as examples the English Revised Version of the Bible $(1881,1885)$ and the corresponding American Standard Version (1901): because of the awkward syntax, these translations "do not communicate effectively," and they are often quite difficult to decipher (20).

Many important developments in the twentieth century have brought about "radical changes in translation principles" (Nida, 21). Great advances in technology and mass communication have made our world ever smaller, bringing people of all cultures and languages in closer contact. The growth of and focus on the field of structural linguistics have brought about, according 
to Nida, the "liberation of translators from the philological presuppositions of the preceding generations" (21). And finally, research into and attempts at the development of machine translation - regardless of its successes or failures - have heightened our appreciation of the difficulties inherent in translation, and focused attention on translation theory and semiology (Nida, 21).

\section{TRANSLATION: ART OR SCIENCE?}

One of the most famous debates surrounding translation theory has been regarding the status of translation as an art or as a science. Proponents of the former position have included Peter Mark Roget and Sir Alexander Fraser Tytler, who, in 1852 and 1907 respectively, referred to translation as "a department of literature" (in House, 5). Reflecting a similar opinion, Flora Ross Amos in the 1920's deemed translation "a vital part of our literary history" (xiii).

In the 1930's and 40's, however, the focus of translation shifted to linguistics - inspired mainly by the works of Eugene A. Nida in the United States and Andrei V. Fedorov in the Soviet Union (Lefevere, 7). In 1953, the Russian linguist maintained that language and its science - linguistics - were the only common denominator of all various types of translation, thus establishing the precedent for the consideration of translation as a linguistic operation, and, the following year, the International Journal of American Linguistics (IJAL) devoted an entire issue to translation (House, 6). The appearance in 1958 of the prominent text Stylistique comparée du français et de l'anglais by Vinay and Darbelnet is further evidence of the movement 
toward a linguistics-based theory of translation. With Ferdinand de Saussure's linguistic theory as its basis, the authors also assert that translation be recognized primarily as a linguistic function. While acknowledging the need for some latitude (because of the lack of equivalence between languages), the authors recommend strictly defining and limiting the freedom allowed the translator to "stray" from the literal meaning of the original text:

Grâce à la stylistique comparée, on doit arriver à ne s'écarter de la littéralité que pour satisfaire aux exigences de la langue d'arrivée. En d'autres termes, on ne doit pratiquer la traduction oblique qu'à bon escient, et dans des limites nettement définies. On doit rester littéral tant qu'on ne fait pas violence à la langue d'arrivée. On ne s'écarte de la littéralité que pour des raisons de structure ou de métalinguistique et on s'assure alors que le sens est sauvegardé. (267-68)

Roman Jakobson also defined translation in linguistic terms: "translation involves two equivalent messages in two different codes" (in House, 12), and, throughout the 1960's, further support for the consideration of translation as the object of scientific investigation was introduced (cf. Catford, 1965; Nida, 1964; Nida \& Taber, 1969). In addition, the advent of the possibilities of machine translation fueled the quest for a precise linguistic description of translation and the assertion that "problems of grammatical and semantic structure should be given priority over aesthetic and stylistic matters" (House, 9-10).

Opposition to this translation-as-quantifiable-science movement has been active as well: Théodore Savory maintained that it was impossible to ever objectify translation - to reduce it to principles - that it is indeed an art rather than a science (28), and in 1957, Edmond Cary argued that, while he 
supported Fedorov's theory of linguistics as the "common denominator" of all types of translation, there is a creative aspect which outweighs the linguistic exercise:

Pour traduire, il faut connaitre les langues, mais la difficulté du problème réside justement dans le fait que traduire de la littérature est... une opération littéraire, traduire des vers, une opération poétique... traduire un livre d'enfant ou un texte technique est, chaque fois, une opération sui generis,... irréductible à un exercice linguistique, fût-il qualifié d'activité créatrice. (186)

Also a critic, Lefevere distinguishes two phases of the broad linguistics-based school of translation theory. The dominant concept of the first, "equivalence," was limiting in that "...any approach to translation dominated by equivalence is likely to focus on the word as the unit of translation, since words can be pronounced equivalent to other words more easily than sentences can be pronounced equivalent to other sentences, paragraphs to other paragraphs, or texts to other texts" (7). And when the focus of translation is on the single word, much of the broader message of the passage or the text as a whole may be missed. Lefevere considers Nida's technique of "componential analysis" - splitting words up into their components to clarify their meaning and facilitate their translation, and gives an example of the shortcomings of such a theory: if one were to define "bachelor = male + unmarried," might not a potential equivalent be "pope"? This term comprises the "bachelor" definition, but also includes "somewhat more." Indeed, as Lefevere concludes: 
This realization... is what froze the first linguistics-based attempts at thinking about translation on a level they could not go beyond and what proved in the end to have limited relevance to translators and translation scholars: a sentence is always 'somewhat more' than a string of equivalent words, and a text is always 'somewhat more' than a string of equivalent sentences (8).

The second phase of linguistics-based translation theory focused on "text linguistics" (Lefevere, 8). An advocate for this shift can be found in Wolfgang Dressler, who suggests that the application of a "suprasyntax" or "textsyntax" is necessary "because equivalence of the entire text is more important in translation than equivalence of smaller units like the sentence" (in House, 9). According to Lefevere, this shift in focus "adds a much-needed functional dimension to the analysis of the translation process and the analysis of translated texts," because the "unit of translation... is no longer the ideal contextless sentence but the text as such... [which is seen]... not as an isolated verbal construct but as an attempt at communication that functions in a certain way in a certain situation or culture and may not work with the same degree of success in another situation or culture" (8).

Nida describes this broadening of the factors taken into account when translating as follows:

The different ways in which people go about the task of interlingual communication can perhaps be best described in terms of different perspectives: (1) the source text, including its production, transmission, and history of interpretation, (2) the languages involved in restructuring the source-language message into the receptor (or target) language, (3) the communication events which constitute the setting of the source message and the translated text, and (4) the variety of codes involved in the 
respective communication events. These four different perspectives could be regarded as essentially philological, linguistic, communicative, and sociosemiotic. (1991:21)

Nida goes on to assert that these four perspectives on translation (and interlingual communication in general) are not mutually exclusive, but rather should be viewed as "complementary and supplementary," and he suggests that the "focus of attention has shifted from emphasis on the starting point, namely, the source text, to the manner in which a text is understood by those who receive and interpret it" (1991:21).

Further support for this perspective is provided by Dwight Bolinger who acknowledges that translation may be viewed from two different standpoints and uses as an analogy the Saussurian model of la langue and la parole: language as the general, static construct with its rules, as opposed to speech as the unique, personal event. He asserts that translation:

...may be viewed amorphously as the rendition of a text from one language to another. This is translation from the standpoint of la parole: the text, the act of speech or writing is the thing. Or it may be viewed as a systematic comparison of two languages: this is translation from the standpoint of la langue (in House, 11).

In fact, the debate over translation as an art or as a science is erroneous because translation is both. In the words of Georges Mounin "...comme la médicine, la traduction reste un art, mais un art fondé sur une science" (1617). The creative, dynamic quality of translation is becoming more appreciated. Consider, for example, the fact that even the great works of literature which have been translated many times are continually being retranslated: every individual, as a product of his or her age and culture, 
brings to the translation process his or her own perspective from which different aspects of the text stand out. In the words of House, translation is the "dynamic process of two languages, two cultures being brought together" (14). Similarly, Mounin asserts that "la traduction... est un contact de langues, est un fait de bilinguisme" (4).

Indeed, recent years have seen a more essential transformation in the debate over the nature of translation. There exists a strong desire to move beyond viewing translations in terms of the traditional dichotomies of right versus wrong, faithful versus free, etc. According to Lefevere, the tendency to view translations in this manner is the result of centuries of using translations as a language-teaching tool, and "because institutions (the church, the state and its educational system) were interested in ensuring that the books most often translated were translated the 'right' way, that the translations of, say, the Bible and the Greek and Roman classics were 'faithful,"' (6). However, this view is becoming recognized as far too limiting: "Such a tradition is forced to neglect all kinds of other aspects connected with the phenomenon of translation, a circumstance that could teach us many things about how cultures and literatures function" (Lefevere, 6).

In The Translator's Turn, Douglas Robinson considers the translator's practice of apologizing in his or her preface for the imperfection of the resulting work, and takes issue with the goal of translation as the attempt to create a parallel text as opposed to emphasizing the learning and growth that the process itself initiates. Robinson criticizes the tradition of considering (1) the translator's work as dualistic: based on the fundamental right / wrong, good / bad, mind / body dichotomies, (2) his role instrumentalistic: he acts as an instrument of and insofar subservient to the original text and author, and 
(3) his attitude as perfectionistic: his goal is to create an exact reproduction of the original work in the target language which is impossible (101-117). Robinson argues that our autonomic responses to language - a word, a rhyme, or a text as a whole, are a fundamental factor in our understanding of and appreciation for a work of literature. Therefore, the translator's "intuitions," or "gut reactions" about the choice of a word or the solution to a particular translation problem, which are ordinarily dismissed as too subjective, are in fact critical to the translation process. The translator's relationship to the original text as well as to his or her internal "turn" from source to target language is - to use Buber's terminology - "dialogical" (xv) and he or she must pay attention to the feedback.

According to Robinson, an important quality the effective translator possesses is "somatic polyphonia" (106). Consider as an extreme example of the importance of this quality - the attention to the feelings that the sounds of language produce - the attempt at "impossible" translation, such as that of Lewis Carroll's "Jabberwocky." This apparently nonsensical poem tells a vivid story by conjuring images through the use of neologisms whose phonemes have strong associations with existing concepts: the adjective "slithy," for example, denotes to any English-speaking person "slippery" + "slimy" + "writhing" = a snake-like quality. The translator must be attuned to the onomatopoeic effect that the neologisms have on him or her and be able to create words in the target language which produce a similar effect.

In the introduction to her translation of André Breton's Amour fou, entitled Mad Love, Mary Ann Caws presents herself as another opponent of the dualistic tradition of translation evaluation. In her words, it is "not a question of being 'right' or 'wrong,' or then 'faithful' or 'fickle' - rather, more of 
trying to express the ongoing and deep relation of the translation to the original, they being complementary in nature as if they were signifying fragments of some larger whole." She also emphasizes the intuitive and empathetic qualities that a translator must have. According to Caws, translation reveals "an interior and impulsive correspondence" with the source text (xvii).

In conclusion, as the complexity of the translation process is better appreciated, we see that it involves neither the strict implementation of a well-defined set of linguistic rules or guidelines, nor the entirely subjective interpretation and imitation of the original work, but rather a constant "juggling" of these two extremes and all degrees of the "gray area" in between. We can then begin to understand the difficulties as well as the creativity involved in the translation process. 


\section{CHAPTER III}

\section{MISE EN SCENE: THE AUTHOR AND THE TRANSLATOR}

Despite the world of differences in the social, cultural and educational backgrounds of Haitian author Jacques Roumain and American poet Langston Hughes, they developed similar political and social views which established a fundamental philosophical bond between them. Because each man had an understanding of and a deep respect for the other's work and goals, a study of the differences between Hughes' translation of Roumain's novel reveals some interesting questions regarding the interpretation of a literary work and the possibilities and limitations of translation. Because a familiarity with these remarkable men's lives and careers helps the critic to more fully appreciate the nature and depth of their common beliefs as well as the "message" of their texts, a brief outline of the life and work of each follows.

\section{JACQUES ROUMAIN (1907 - 1945)}

Jacques Roumain was born June 4, 1907 in Port-au-Prince, Haiti. His father, Auguste Roumain, was a wealthy land owner, and his grandfather, Tancrède Auguste, had been president of Haiti for a brief period during the tumultuous years between 1843 and 1915. He was accused of having assassinated his predecessor in office by blowing up his palace, and was poisoned in 1913 (Ormerod, 17). Roumain was educated "in the best French 
tradition" (Bostick, 6): he attended St. Louis de Gonzague School for boys, and at age fourteen, was sent to Switzerland. In Berne and Zurich, Roumain broadened his knowledge of the German language and culture, and studied nineteenth century German philosophers and poets. He also studied several poets of the Near East, notably Umar Khayyam ("Poète et mathématicien persan... Son angoisse lui fait célébrer dans ses Quatrains la jouissance immédiate de la vie, " [Petit Larousse]) and Ibrahim Muhammad Hafiz, a lyric poet often called the "poet of the Nile," who influenced Roumain's writing as well as his later political activity (Bostick, 6).

Roumain's travels took him to Germany, France, England and, in 1926, to Spain where he intended to study agronomy. Here he developed not only his fluency in Spanish, but also a love of bullfights, and he discovered the writings of the French essayist, novelist and playwright Henry de Montherlant ("Auteur de romans qui exaltent la vigueur physique et morale... ou expriment une vision de moraliste désabusé," [Petit Larousse]), whose poem "Les Bestiaires" made a strong impression on Roumain (Bostick, 6).

Roumain was inspired by his education and anxious to put to work his new philosophical and political ideas. In 1927, barely twenty years old, he wrote in response to the American occupation of his country: "I am eager to return to Haiti to help raise again the courage of the masses and to lift the burden of her people" (in Bostick, 7). Upon returning to Haiti, Roumain waged his war with words. An ardent supporter of the "Indigenous" movement, he founded La Revue Indigène (1927), "...in which a national literature based on an indigenous Haitian reality could find its expression" (Dash, 6). He published poems, short stories and translations from Spanish and German, and - along with a small group of writers - was actively 
struggling to establish a new thought and art form based on the knowledge and pride of self. Roumain's "life-long quest" was to "rid the Haitian people of their burdens both foreign and domestic" (Bostick, 7).

Roumain's actions were not only literary: in 1929 he was imprisoned for the first time for counter-occupation political activity. He was released, arrested again a few months later, and, after a sensational trial, sent again to prison for "délit de presse," publishing subversive articles (N.B., 8). With the triumph of nationalism in Haiti in 1931, Roumain, only twenty-four years old, was named director of a branch of the Department of the Interior. As his political and social views developed, however, it became impossible for him to continue his collaboration with the Government, and he left this post. Marxism, Roumain was coming to believe, provided not only an explanation for the social and economic disparities in Haiti, but a possible solution to these problems (Dash, 7). He was arrested in 1933 and again the following year after having founded the Haitian Communist Party. After three years in prison, he left for Europe in poor health. He spent a year in Belgium, then enrolled in the Institute of Ethnology at the Sorbonne's Institut de Paléontologie Humaine where he worked as an assistant to Paul Rivet at the Musée de l'Homme (N.B., 9).

When the Second World War broke out, Roumain left Paris for the United States. In 1939, he published a Marxist analysis of the condition of the black American in the South entitled Griefs de l'homme noir in which he theorized that racial prejudice in general - and the phenomenon of lynching in particular - was encouraged by the ruling classes to impede the unifying of the blacks and poor whites in an attempt to change the social order (Dash, 7-8). In the United States, Roumain continued his science studies at Columbia 
University in New York. He visited the island of Martinique, and in Havana, Cuba he worked for a year with the poet Nicolas Guillen. When President Elie Lescot came to power in 1941, his "anti-Fascist stand...allowed Roumain to make his peace with the [Haitian] government..." (Dash, 8). He returned to Haiti where he founded and directed the Bureau d'ethnologie de la république d'Haiti and was a professor of Pre-Colombian Archeology and Prehistoric Anthropology. He was extraordinarily active with travel, research, and archeological digs as well as with his writing.

At this time, the Catholic Church was trying actively to convert the followers of Voodoo through its "campagne anti-superstitieuse." Roumain spoke out against this movement not because he believed that the voodoo faith was the answer to his country's suffering, but because he felt that neither religion addressed the real needs of the people. In an essay entitled "Autour de la campagne anti-superstitieuse," he wrote:

The essential is not to make the peasant renounce his belief in Ogoun. It is rather a question of completely changing his conception of the world... The element of moral coercion used in this campaign is fear... But fear of hell fire has not radically changed their religious view of the world. They have not renounced their belief in the "loas" only their serving of these gods... If one really wishes to change the archaic religious mentality of our peasants, we must educate them. And they cannot be educated unless their material conditions are transformed. Until we have developed a system of rural clinics, the peasant will continue to consult his bocor (priest). What we must have in Haiti is not a campagne anti-superstitieuse but a campagne anti-misère. (in Dash, 8-9) 
In 1943, Roumain was offered and accepted a diplomatic position as chargé d'affaires in Mexico. There he fell ill ("frappé d'une crise soudaine dont l'issue tout de suite parut fatale, " [N.B., 10]), recovered only for a short time, and returned to Haiti where he died on August 18, 1945 - officially of cirrhosis of the liver - "dans la pleine maturité de son être et de son talent" (N.B., 10).

This extraordinary man - poet, novelist, journalist, diplomat, politician and ethnographer - succeeded, according to Roussan Camille, "in achieving by his engaging personality a very rare phenomenon: the complete harmony between life and ideas" (in Bostick, 6).

Herman Bostick describes the evolution of Roumain's poetry from "descriptive" to "protest" poetry: noting the influence of the French romantic poets on the former and, in the latter, "a strident denunciation of the status quo and an aggressive call to action to bring about a new social order based on freedom and international brotherhood" (14). Bostick aptly titles his article: "From Romanticism to Militant Optimism: The Poetic Quest of Jacques Roumain." Bostick also considers examples of Roumain's poetry which reveal important aspects of his character, such as the rejection of his French ancestry:

Your soul is the reflection in the murmuring waters where your fathers bent their dark faces.

And the white man who made you a mulatto, it is this bit of scum, like spit, on the shore. (in Bostick, 10) 
Likewise, his strong criticism of organized religion is expressed clearly in the following excerpt:

...But today Christ is in the den of thieves and

His arms stretched out in cathedrals shadow of the vulture.

And in the basement of monasteries priests count the interests on thirty pieces of silver and the church's bell towers spit death on the hungry multitudes. (in Bostick, 13)

Although the experiences of their early years were very different, Jacques Roumain and Langston Hughes both traveled extensively and shared a keen intelligence, perceptiveness, and social consciousness which united them philosophically.

\section{LANGSTON HUGHES (1902 - 1967)*}

In Joplin, Missouri, on February first, 1902, Langston Hughes was born into a middle-class family. Hughes' parents separated when he was quite young, and he lived for a period with his grandmother in Lawrence, Kansas. Dickinson describes Hughes' boyhood as having been lonely but not desolate: he discovered race animosity as the only black child at a white elementary school, but also discovered his love of books at the Topeka Public Library. In spite of the abuse - verbal and sometimes physical - that he suffered, Hughes was able to maintain a "faith in humanity" and optimism

*Unless otherwise cited, the following bibliographic information is drawn from Dickinson. 
regarding the future of race relations. His insight and optimism are especially evident in his early poem entitled "I Too":

\author{
Tomorrow, \\ I'll be at the table \\ When company comes. \\ Nobody'll dare \\ Say to me, \\ "Eat in the kitchen," \\ Then. \\ Besides, \\ They'll see how beautiful I am \\ And be ashamed - \\ I, too, am America. (in Dickinson, 10)
}

At the age of twelve, Hughes moved to Lincoln, Illinois to live with his mother and step-father. He was elected "class poet" and chosen by his classmates to write a graduation poem: because he was black, they assumed that he had "natural rhythm." When he stood and delivered his composition, Hughes remembers: "everybody applauded loudly. That was the way I began to write poetry" (Dickinson, 9).

Hughes' interest in foreign languages was also sparked early. He moved with his family to Cleveland, Ohio in 1916 where he attended high school and met for the first time blacks from the south as well as Russian, Polish and German immigrants, many of whom were Jewish, and one of whom introduced him to Guy de Maupassant. He recollects: "I think it was de Maupassant who made me really want to be a writer and write stories about Negroes, so true that people in far-away lands would read them - even after I was dead" (in Dickinson, 10). Hughes spent the summers after his junior and senior years with his father in Mexico where he learned Spanish as 
well as some German from his father's housekeeper. He studied French in high school and at Columbia University, which he attended less for academic reasons than for the chance to see Harlem. Not surprisingly, he dropped out after his first year, and proceeded to work odd jobs in the New York area. In 1923, he was hired as a cook's helper on a tramp steamer to Africa and Europe. The following year, he worked for a time as a cook in a Paris night club, then returned to the United States to live with his mother in Washington, D.C. Hughes described this period as frustrating: while it was easy to forget racial injustice while in Europe, conditions were not nearly as favorable in his own country.

In 1926, Hughes entered Lincoln University in Pennsylvania from which he graduated in 1929. In the years that followed he traveled a great deal: in 1930 to Haiti, in 1931 he conducted a poetry reading tour of the southern and western United States, and in 1932, he traveled to Russia. In 1933, he returned to California after visiting Japan. He spent a year at Carmel by the Sea, received a Guggenheim Fellowship in 1935, and in 1937, left for Spain as a corespondent for the Baltimore Afro-American. In 1941 he received the Rosenwald Fellowship, and, in 1943, an Honorary Literary Degree from his alma mater, Lincoln University. In 1946 he was elected a member of the National Institute of Arts and Letters. He spent two years as a visiting professor at Atlanta University (1947-48) and a year as poet-inresidence at the University of Chicago's Laboratory School in 1949. He was granted the Ainsfeld-Wolfe Award for the best book of the year on race relations in 1953, the Spingarn Medal in 1960, and another Honorary Literary Degree in 1964, from Western Reserve. Langston Hughes died on May 22, 1967. 
Although an "amateur translator" (Hodges, vi; Guillaume, 3), Hughes recognized both the difficulties and importance of translation. He acknowledges in his introduction to An African Treasury: "To communicate in words is not always easy, especially when those words must be put down on paper. To communicate from one land to another, one culture to another, particularly when the language is not one's native tongue but acquired... presents its problems" (Guillaume, 3). He learned, particularly in his travels, the primary importance of learning foreign languages and of translation as an instrument for inter cultural harmony: "understanding another person's language is the first step toward understanding the person..." (Dickinson, 108). Guillaume points out that Hughes was:

...interested in social and political change and reform. For Hughes, translation was not simply an aesthetic exercise, but an effective method of sharing with an English-speaking audience the universal message of social justice... As translator, Hughes was first and foremost an interpreter of ideas... His task was to transfer ideas and sentiments from one language to another, to re-create in English the intentions of the original language.

Dickinson concludes that, in this respect, his "...translations seem to be Hughes' modest offering toward a better world understanding" (Dickinson, 108).

"SHARED VISION"

Jacques Roumain was familiar with Langston Hughes' poetry before meeting him and was "deeply moved by this black poet from the United 
States who sang about black peoples" (Bostick, 10). Roumain even wrote a poem entitled "Langston Hughes" which emulates the rhythm of Hughes' own poetry and describes the protagonist's rejection of American culture and the affirmation of his African heritage. The poem "highlight[s] the common ancestral heritage of the black diaspora through the portrayal of a black male who savors the pleasures of women of easy virtues in Lagos, Dakar, Paris and Venice. The escapade of this traveler ends during the early morning hours in a cabaret in Paris as he calls out presumably to a black musician,

\section{Jouez se blues pou'moa \\ O jouez ce blues pou'moa}

(Play those blues for me

O play those blues for me)"

"Langston Hughes" (in Bostick, 10).

Roumain's influence on Hughes was no less significant. In 1946, Hughes wrote a eulogistic poem for Roumain, "A Poem for Jacques Roumain (Late Poet of Haiti)," in which he expresses his admiration and respect for his late friend:

You've gone

But you are still here.

From the point of my pen in New York

To the toes of the blackest peasant

In the morne [hill]

Always

You will be

Man

Finding out about

The ever bigger world 
Before him.

Always you will be

Hand that links

Erzulie to the Pope

Damballa to Lenin,

Haiti to the universe

Bread and fish

To fisherman

To man

To me... (in Fowler, 88)

Langston Hughes and Jacques Roumain met on several occasions, the first of which was in 1931 when the former traveled to Haiti to write for a summer. Already an accomplished poet, his reputation preceded him, and Roumain greeted him as "the greatest Negro poet who ever came to honor Haitian soil" (in Guillaume, 2). For his part, Hughes described Roumain after their first visit as "one of the few cultured Haitians who appreciated native folklore, and who became a friend of the people without shoes" (in Berry, 125). The two met again in 1932 when Roumain visited New York and Washington, D.C. to establish contact with the Communist Party of the United States in order to help found a Communist Party in Haiti. Finally, in 1937, Hughes and Roumain were reunited as two of the guest speakers at the "Second Congress of Writers for the Defense of Culture" in Paris (Fowler, 86).

Carolyn Fowler describes Hughes and Roumain as both part of the "African Diaspora": "Both had sought, across national and racial lines with other humanists, to raise the level of sensibility and morality in their world. Yet, each had remained firmly rooted in his own culture, and the best creative 
work of each had grown out of the rich matrix of that culture" (85): the "essential bond" between them was that they "shared the vision of writer as humanist, as the conscience and the voice of his people" (87). Both Hughes and Roumain advocated the involvement of writers: they "shared a vision of the function of art as the articulation of a people's condition, as a reflection of the culture which that people develops to cope creatively and to express their hope for the fulfillment of universal human aspirations" (Fowler, 88). In the words of Roumain, "...the primordial mission of a man of thought [is]: To Be A Man of Action [sic]" (in Fowler, 87). When Roumain was arrested, tried in what Hughes deemed "an unfair trial," and sentenced to three years in prison in the summer of 1934, Hughes wrote letters of protest including the following "Appeal for Jacques Roumain" which was published in several journals:

Jacques Roumain, poet and novelist of color, and the finest living Haitian writer, has just been sentenced at Port-au-Prince, Haiti to two [sic] years in jail for circulating there a French magazine of Negro liberation called Cri des Nègres. Jacques Roumain is a young man of excellent European education, and formerly occupied a high post in the Haitian government and is greatly respected by intellectuals as an outstanding man of letters. He is one of the very few upper-class Haitians who understands and sympathizes with the plight of the oppressed peasants of his island home and who has attempted to write about and to remedy the pitiful conditions of 90 percent of the Haitian people exploited by the big coffee monopolies and by the manipulations of foreign finance in the hands of the National City Bank of New York.

As a fellow writer of color, I call upon all writers and artists of whatever race who believe in the freedom of words and of the human spirit to protest immediately to the nearest Haitian 
Consulate the uncalled for and unmerited sentence to prison of Jacques Roumain, one of the few, and by far the most talented, of the literary men of Haiti.

\section{Langston Hughes}

Carmel, California (in Berry, 210)

In a letter from Roumain's widow, Nicole Jacques Roumain, to Hughes, we learn that the author had been eager for Hughes to translate his work. She wrote: "Jacques always thought that you alone were capable of doing this work, let us say of adaptation, from one language to another... the dream Jacques had in Mexico when he finished the novel, of seeing it translated into English and presented to the public by Langston, becomes a reality" (in Fowler, 87). The project did not progress entirely smoothly, however: Mercer Cook (a professor of French) submitted a translation to be reworked by Hughes which was rejected by Doubleday as "too slight to interest American readers" (Rampersand, 112). When the translation was accepted by Reynal and Hitchcock, the $\$ 750$ advance was divided by Roumain's widow who received two-thirds, and Hughes. The agreement was that Cook would be paid only once this amount had been covered by the book's earnings - "requiring the sale of three thousand copies - a most unlikely event" (Rampersand, 119) - and that he would receive only $25 \%$ of the royalties up to $\$ 500$. While Cook apparently had no objections to these terms, Hughes' agent was "annoyed" by them. He reportedly exclaimed: "This is indeed a labor of love!" (in Rampersand, 119). In addition, once Hughes had researched and revised Cook's original translation with Haitian biographer René Pignon, Hughes suggested that his be the only name to 
appear on the title page. His agent, Maxim Lieber was "scandalized," and the idea was dropped (Rampersand, 119).

Given the "shared vision" and great mutual respect of Jacques Roumain and Langston Hughes, it is interesting to consider the differences between the former's original work written in French and Haitian creole and the latter's English translation. Which discrepancies are the result of differences in interpretation, and which are a question of "intranslatability," that is, the impossibility of perfectly transferring ideas from culture to culture and language to language? Were the translators more concerned with authenticity, maintaining the flavor of the original work, or with the accessibility of the original work's message to the target culture of 1940's America? A comparison of these texts - each a successful work of literature in its own right - highlights the translator's science and art: the continual juggling act and decision-making process. 


\section{CHAPTER IV}

\section{GOUVERNEURS DE LA ROSEE}

\section{ORIGINS OF ROUMAIN'S TEXT}

In Gouverneurs de la rosée, Roumain succeeds in conveying important social and political messages through a beautifully crafted work of art. Neither glorifying nor pitying the Haitian peasants whose plight he describes, Roumain draws the reader into their world through his own empathy and caring. Hope is a dominant theme in the novel: while strongly critical of the state of the land as well as the relations between the people of Haiti, the overriding message is one of optimism for a new beginning. Following is an overview of the origins and the unique qualities of the novel, an understanding of which heightens the appreciation for the difficulties that its translation presents.

While chargé d'affaires in Mexico in 1944, Roumain completed the manuscript for the novel that would be published posthumously because of his sudden death a few months later. Gouverneurs de la rosée became, according to Henri Micciollo "...en quelque sorte le porte-drapeau de la littérature haittienne" (11). Once published, the novel was highly praised, "considered a classic by most critics and eventually translated into a dozen languages" (Dash, 9). In his introduction to Hughes' and Cook's translation, J. Michael Dash highlights the unique qualities of the Haitian peasant novel. 
He points out that it distinguishes itself from the "contemporary novel of the Third World that tends to be inspired by anti-colonial protest and the angst of the 'assimile' torn between the culture of the metropolis and that of his native land" (10). As Dash suggests, the movements of Realism and Naturalism as well as the theory of determinism which were evolving during the nineteenth century in France greatly influenced the Haitian peasant novel. The role of the novel became that of a detailed record, a "mirror" of society, and "sociological investigation of the environment that determined and shaped the individual" (Dash, 10). An important element of this sociological investigation was a heightened social consciousness: "What Zola had done for the urban poor in France, the Haitian novelist wished to do for his peasantry" which was more than to simply depict or portray "local colour," but rather to expose "the harsh realities of peasant existence" (Dash, 10).

The most prominent Haitian precursors to Roumain's Gouverneurs de la rosée include (1) La Famille des Pitite-Caille, written in 1905 by Justin Lhérisson who used a narrative framework which reflects the Haitian oral tradition to relate "the adventures of a 'nouveau riche' protagonist of peasant origins...[who] is mercilessly satirized in a mixture of creole and standard French" (Dash, 10-11); (2) Mimola, by Antoine Innocent which was published in 1906, and which describes voodoo rituals in such detail that "they verge on ethnography" (Dash, 11); and in particular (3) Price-Mars' famous Ainsi parla l'oncle written in 1928: the chef d'cuvre of the Indigenous movement, this novel "created widespread literary interest in the peasantry. This work severely criticized the cultural ambivalence of the traditional élite as regards the peasantry and encouraged the belief that the culture of the peasant was a valid source from which one could draw literary 
inspiration" (Dash, 11). All of these works inspired and have elements in common with Roumain's novel, and helped to pave the way for its impact and success.

The story line of Gouverneurs de la rosée is quite straightforward: Manuel, the novel's "prodigal son," returns to his home town of Fonds-Rouge after fifteen years of labor in the sugar cane fields of Cuba to find his village and countryside drought-stricken and divided by a feud. Manuel is determined to rescue his people: he finds a spring, organizes a group labor force to forge an irrigation system which, in the process, reunites the feuding clans. Not all in the village approve of the new "savior," however: he is beaten severely by the jealous cousin of Annaise, a girl from the opposing clan with whom he falls in love. Manuel dies as a result of this attack, but the reader learns in the novel's last scene that Annaise is pregnant with his child, symbolizing the flourishing of the new life that Manuel has bestowed upon his village.

Although the plot of Gouverneurs de la rosée is simple, Roumain creates a powerful and moving story. As Beverly Ormerod points out:

The drought is typical of the region, and the manner of the protagonist's death is not unusual in the Caribbean. It is a measure of the novel's strongly symbolic tone that the reader does not think of it in these practical, low-key terms, but in terms of passion, heroism and sacrifice. The great dignity of the narrative, and its ritual, fatalistic quality, are achieved in the first place by the sense of a firm and inevitable time-scheme in which all the characters and events have their appointed place... (1920) 
While outlining Roumain's use of religious symbolism, Ormerod credits Michel Serres with defining the three temporal stages through which the novel passes: "the lost Eden, the parched and weary waiting, and finally the arrival and death of the Redeemer" (in Ormerod, 20). Indeed, the images of a "paradise lost" abound in the contrast between the description of the existing dead and dying surroundings (the ashes, the dust, the erosion of the earth), the reminiscence of past lushness (the water, the vegetation, the solidarity of the inhabitants), and the hope for the future as manifest in the return of water to the region.

One of the most prominent features of Roumain's novel is the primary role of nature. As stated by Patchechole Poindexter Ojo, "Caribbean authors... who show tremendous sensuous awareness of the nature world are most successful because they demonstrate their metaphysical interpretations of their realities through explicit uses of nature" (89). Ojo describes Roumain's "artistic as well as metaphoric use" of nature, and emphasizes that Roumain neither glorifies nor over-dramatizes the state of the land, but rather creates a character of the earth who responds according to the manner in which she is treated: she is protecting and life-giving when respected and cared for, or she is harsh, threatening and desolate when abused or mistreated. This anthropomorphism of the earth gives the reader respect and empathy for the earth's condition.

Here is a very strong case of nature in the role of protagonists, (the antagonists being the men who raped the land and caused the water to dry up), and a Caribbean author boldly denouncing exoticism and portraying instead a realistic, loving picture of a hard life but one which has qualities of beauty and pathos not readily perceived by the outsider. His descriptions 
are evocative, but it is in the final analysis the metaphysical qualities with which they are imbued that make the novel so dramatic. (Ojo, 99)

The primary forms that nature as the protagonist takes are earth and water: "Two forces which go hand in hand are at work: the land, and water. The land represents home, man's body, survival. Water represents his lifeblood, his heartbeat, his capacity to live and promulgate" (Ojo, 97). These images abound in every description of the earth and water: a prime example is the scene (very much like Adam and Eve in the Garden of Eden, "-Au commencement $d u$ monde...") in which Manuel reveals to Annaïse the spring that he has discovered. Here Annaïse's body seems to become one with the earth, and she feels the water, like her own blood, coursing through her veins: "Elle était étendue sur la terre et la rumeur profonde de l'eau charriait en elle une voix qui était le tumulte de son sang" (117). It is no coincidence that this is the scene in which Manuel and Annaiise make love and begin a new life.

In addition to this symbolism, the poetry of Gouverneurs de la rosée sets the novel apart as beautifully written and expressive and captivates the reader. From the first page, he is drawn into the world of Manuel through Roumain's masterful use of language. Roumain blends a "creolized French," rich metaphors and other poetic tropes to give the novel the feel of Haiti. Roumain not only includes Haitian creole terms, songs and expressions, but he also captures the qualities of creole speech in the standard French spoken by the novel's characters through its syntax. This is evident in the dialogue of the novel's characters: "- Bonjour, maman ; papa, je te dis bonjour, oui" (45) and "Ay, mon fi, c'est que c'est la vérité, oui" (48), for example. 


\section{FEATURES OF ROUMAIN'S TEXT}

\section{Alliteration, Assonance and Repetition}

Quite frequently, Roumain uses the poetic tropes of alliteration and assonance as well as the repetition of words and phrases to strengthen the impact of his writing. Consider, for example, the emphasis added by the recurring / $/ \mathrm{k}$ sound in "couper la canne à sucre à Cuba" (23). The harshness of the sound underscores the brutality of the work involved (it is assumed that Manuel would not have been able to survive the years of hard labor: "Il doit être mort maintenant," [23]). In the same manner, the stridulation, the shrill, chirping sound of swarming locusts, is recreated in the /s/ repetition of: "... une fine vapeur dansait et vibrait comme un essaim dans le silence que seul troublait le stridulement acide des criquets" (21). Another statement which conveys its message through the meaning as well as the sound of its words is "Le malheur bouleverse comme la bile" (12). The onomatopoeic quality of "bouleverse" is emphasized by the repetition of $/ \mathrm{b} /$ and $/ /$ which gives the phrase a rolling, tumbling, "bouleversant" feeling. Similarly, in the phrase, "Au-dessus des bayahondes flottent des haillons de fumée..." (17-18), the reader feels the floating motion of the "tatters of smoke" (Hughes, 28) through the alternating /õ/ and /f/ sounds which accentuate the rising and falling meter of the passage.

Finally, Délira's rhythmic plea to the Virgin Mary resembles a chant because of the stress pattern which is accented by the repetition of "les" as well as of the /t/ and /ã/ sounds: "nous mourrons tous : les bêtes, les plantes, les chrétiens vivants" (11). And similarly, the peasants' misery is underlined 
in the repetition found in Bienaimé's theory regarding their situation and fate: "Eh bien, la terre est dans la douleur, la terre est dans la misère, alors, le Seigneur c'est le créateur de la douleur, c'est le créateur de la misère" (12).

\section{Metaphor}

Roumain succeeds in bringing to life Haiti's landscape for the reader through his vivid descriptions and anthropomorphism of the earth. For example, the following passage eloquently describes the awakening of the land:

Peu à peu les arbres noircis, leur feuillage encore chargé de lambeaux d'ombre, reprenaient leur couleur. Une huile de lumière les baignait. Un madras de nuages soufrés ceignait le sommet des mornes élevés. Le pays émergeait du sommeil.

Most often, however, Roumain's depictions of the earth underscore the destruction that has been inflicted upon it, as in the following passage:

Derrière la maison, la colline arrondie est semblable à une tête de négress aux cheveux en grains de poivre : de maigres broussailles en touffes espacées à ras de sol; plus loin, comme une sombre épaule contre le ciel, un autre morne se dresse parcouru de ravinements étincelants; les érosions ont mis à nu de longues coulées de roches : elles ont saigné la terre jusqu'à l'os. (13) 
Here, the image of the earth as a black woman having been first "stripped," then "bled to the bone" vividly portrays the tragedy of the violence committed by man to what had been Haiti's lush and fertile land.

\section{Narrative Style}

The reader takes part in the events of Gouverneurs de la rosée because he is drawn into the action through Roumain's use of the first person narrative. The frequent use of the French subject pronoun "on" which corresponds to the English personal pronoun "one" but also implies "we" - the narrator and by extension the reader are included in the action: "...,diraiton,..." (11), "On entrait dans l'herbe de Guinée !" (14), "On était déjà mort dans cette poussière,...mais on avait bon courage et après s'être gourmé avec la terre, après qu'on l'avait ouverte, tournée et retournée,..." (22). Occasionally, the reader is even addressed directly: "...et si tu voulais $d u$ riz..." (20).

In her article entitled "The Nature, Function, and Performance of Indirect Discourse in Prose Fiction," Judith Espinola differentiates between "direct" and "indirect discourse," and the effects that these different narrative styles have on the reader. "Direct discourse" clearly presents the thoughts or speech of a character as reported by the narrator as in: "'We're all going to die,' said the old woman" (23). "Indirect discourse" - and "free indirect speech" in particular - on the other hand, are used as a means of revealing a character's thoughts and feelings: "narrators employ free indirect speech as an excellent medium for the conveying of inner life... when a narrator needs to organize a character's random thoughts and feelings into language which will 
be readily understood by the reader" (Espinola, 202). Consider as an example the following passage from the first page of Roumain's novel:

La poussière monte de la grand-route et la vielle Délira est accroupie devant sa case, elle ne lève pas les yeux, elle remue la tête doucement, son madras a glissé de côté et on voit une mèche grise saupoudrée, dirait-on, de cette même poussière qui coule entre ses doigts comme un chapelet de misère : alors elle répète : nous mourrons tous, - et elle appelle le bon Dieu. Mais c'est inutile, parce qu'il y a si tellement beaucoup de pauvres créatures qui hèlent le bon Dieu de tout leur courage que ça fait un grand bruit ennuyant et le bon Dieu l'entend et il crie : Quel est, foutre, tout ce bruit? Et il se bouche les oreilles. C'est la vérité et l'homme est abandonné. (11)

Here Roumain blends (1) "direct discourse": "nous mourrons tous" which is underlined by the "tag" "elle répète :" as the words of the character Délira, (2) "indirect speech": "et elle appelle le bon Dieu" where the narrator renders the character's thoughts using the third person, as well as (3) "free indirect speech," or "narrated monologue" in the long, last sentence of the above paragraph. In this last sentence, the reader senses that the novel's protagonist is addressing him or her directly. That it represents a character's rather than the author's voice is suggested by the language used: the grammatical error, "si tellement beaucoup," as well as the expression of the sense of futility in the face of his situation which is apparent in the opinion that man has been abandoned by God: "C'est la vérité et l'homme est abandonné." This final sentence of the passage has all of the elements of "free indirect discourse" as defined by Ullman: it "avoids explicit subordination, retains the expressive elements of speech, and tries, to imitate 
the inflections and intonations of the speaking voice" (in Espinola, 200). In so doing, this narrative style succeeds in making the action of the novel more immediate because there is no apparent "intervention" on the part of the narrator between the characters and the reader. Espinola emphasizes that "...one very important function of all kinds of indirect discourse is to effect the simultaneous presentation of narrative point of view with character personality and vision" (196). Through this continuous mixing of "direct" and "indirect discourse," "a writer can control the degree of vividness and immediacy which is achieved from one moment to the next, highlighting certain passages to created intended effects [sic]" (Espinola, 201). Using "indirect discourse," and in particular "free indirect speech," Roumain succeeds in drawing the reader into the world of the characters through the immediacy of the action and the sharing of their thoughts and feelings: their despair, their anger, and finally, their hope. 


\section{CHAPTER V}

\section{MASTERS OF THE DEW: STRUCTURAL ASPECTS}

Did Langston Hughes succeed in his attempt to make this rich and unusual text available to an English-speaking audience? In examining his translation, the novel's most prominent features as discussed in the previous chapter are considered (in addition to a few other aspects which generally pose problems for translation), the effects of the original and the translation are compared, and conclusions are drawn as to where the impact or the message of the original was made or lost. The emphasis in this chapter is on the structural aspects of the text, and the translation of Roumain's poetic language is examined in Chapter VI.

Sara Blackburn dubs "Professor Horrendo" he who, rather than appreciating the overall effect of a translation, becomes obsessed with "nitpicking after inaccuracies" (in Rabassa, 82). At the risk of being so dubbed, I believe that a close examination of the similarities and disparities between Roumain's Gouverneurs de la rosée and Hughes' Masters of the Dew reveals not only the successes and failures of the translator, but also helps to better appreciate the most subtle qualities of the source text and clearly demonstrates some of the more general difficulties of translation. 


\section{FEATURES OF HUGHES' TEXT}

\section{Structure and Narrative Style}

An important feature of Gouverneurs de la rosée is Roumain's unusual narrative style. The reader is drawn into the text emotionally and convinced of its authenticity because of the narrator's intimate involvement: at times, he even becomes one of the story's characters. Roumain succeeds in "reducing third person narration to a minimum and presenting a text which seems to be narrated in the first person. Often in descriptive passages it is difficult to tell when the narrator stops and when the thoughts or fantasies of the characters begin" (Dash, 16). Unfortunately, Hughes' translation is not always faithful to Roumain's style, and thus loses some of the original work's power.

Differences in the structure of Roumain's Gouverneurs de la rosée and Hughes' translation Masters of the Dew often reveal differences in the narrative style of the two texts. In his translation, Hughes often changes the paragraphic division as well as the sentence structures of the original. The very first paragraph - that which establishes the tone of the entire novel serves as a good example. In Roumain's work, this first paragraph is a mixture of speech and description: although the fact that one of the characters is the source of the expression is defined by the tag "...la vieille Délira Délivrance dit..." (11), her words are not separated from the narrator's description by punctuation (that is, other than by the initial dash " - Nous mourrons tous... - ") or paragraphic division. Hughes, on the other hand, clearly divides the character's speech and narrator's description first by enclosing the former in quotation marks, and secondly by breaking the text into three paragraphs - the first and third comprising the speech of the 
character Délira Délivrance, and the second clearly the narrator's description of the unfolding scene. The effect of Hughes' decision to separate and qualify the combined direct and indirect discourse of the original text is to establish a clear distinction between the novel's narrator and characters, which results in a distancing of the narrator's involvement in the scene. Roumain's use of indirect discourse suggests the reflections and reminiscences of the narrator in the form of "stream of consciousness," a technique, according to Pascal, that is "...most effective for the conveying of spontaneous internal thoughts and feelings" (in Espinola, 202-203). The sense of his personal involvement in the events of the story is diminished in Hughes' translation and, with it, the reader's involvement in the world that he creates.

At the end of this first page, Hughes removes rather than creates a paragraphic division, but the result of the change is the same. Although the paragraph begins with uncertainty as to the source of the contemplation, Hughes' addition of the tag "Thus thought Bienaimé" (23) removes the question in the reader's mind, thereby reducing the intended effect of the original wording. Espinola describes the difficulty involved in the interpretation of this type of "free indirect speech": "...the language often implies two voices speaking simultaneously and... the complexities involved in coming to terms with the interpretation of indirect discourse are intensified and more often neglected" (195). Unfortunately, this neglect results in a loss for the reader of the translation.

The narrator in Roumain's novel also expresses himself through interjections in the text. The description of the coumbites (14), for example, appears to be partly the reminiscence of Bienaimé, partly the contribution of the narrator because of the interjections of his commentaries such as "parole 
$d^{\prime}$ honneur" and "n'est-ce pas?". Because these commentaries are addressed directly to the reader, he participates in the story in much the same manner as the listeners who react and respond to storytellers of the African tradition who ask "Cric?..." to which listeners respond "Crac!" to begin the interactive tale.

Other omissions of this type on the part of the translator detract from the effect of the original text. Take for example the narrator's commentary: "dans le corps c'est ce qu'il y a de plus récalcitrant, les reins" (19). This important opinion is missed in the translation because it expresses not only the peasants' ability to bear such difficult labor - their unyielding physical strength, but because it also suggests the importance of their life-giving potential and sexuality - "les reins" being the part of the body symbolizing reproductive strength.

At the end of this same paragraph is another example: while in the original text the narrator addresses his threat to the "bourgeois de la ville" with the use of the direct object "vous" and the interjection "salauds" (19), the translation becomes: "But never mind and to hell with them! Some day we will take our big flat feet out of the soil and plant them on their behinds" (29). Although the narrator's voice does appear, the speech is not delivered directly to the "addressees" ("destinataires"). This, in addition to the omission of the curse, results in a lessening of the impact on the reader. Similarly, in describing the abundant feast which followed the coumbite, the narrator involves the reader by suggesting "et si tu voulais du riz..." (20). Lost in the translation, the " $t u$ " at once addresses the reader directly and gives the interjection a familiar and amiable tone. 
Another commentary on the part of the narrator is evident at the end of the novel in the interjection / response to Hilarion's pondering the imposition of a tax on access to the newly-found water: "Je ferais les recouvrements et je mettrais ma part de côté. On verra. (Oui, on verra si les habitants se laisseront faire.)" (189). This narrative interjection is lost in Hughes' attribution of the comment to Hilarion: "But would the peasants stand for it?" (185).

Other choices made by the translator augment the "distancing" of the narrator (and in turn the reader) from the story. For example, the use of the colloquial "on" is translated by Hughes into "they": "On entrait dans l'herbe..." (14) becomes "Into the field of wild grass they went" (25); "On laissait Rosanna s'affairer..." (14) is "Then they would all leave Rosanna..." (26); and further: "On était déjà mort dans cette poussière...mais on avait bon courage..." (22) becomes "They were already dead beneath this dust... But they had persisted..." (32). While the pronoun "on" suggests the inclusion of the narrator, "they" excludes him, and the result is that Roumain's narrator participates in the activities while Hughes' is a detached observer. Therefore, a more effective translation of the expression would have been the use of the first person plural, "we."

B. Follkart di Stefano examines the role that choice of tense plays in a work of literature (in his case, passé composé vs. passé simple) and concludes: "Ideally, then, the translator should perceive - the more explicitly the better - the ideological values underlying the use of tense...; he must see the choice of tense as an artistically meaningful one, in most cases..."(247). With this in mind, the reader of Gouverneurs de la rosée appreciates how the author brings the events of the novel to life by using the présent de narration. 
A weakening of this impact of the original text is found in the disparities between the tenses used in the original and the translation. For example, while Roumain's reflections on the days of the coumbites (collective labor groups) are presented primarily in the present tense, Hughes descriptions are in the past tense: "Au-dessus des bayahondes flottent des haillons de fumée...Estinval essuie du revers de la main ses yeux rougis. De l'arbre mutilé, il ne reste que le squelette calciné des branchages épars dans la cendre: une charge de charbon que sa femme ira vendre..." (17-18) becomes: "Above the thorn acacias floated tatters of smoke... With the back of his hand, Estinval wiped his reddened eyes. From the mutilated tree there remained only the charred skeletons of its scattered branches in the ashes: a load of charcoal that his wife would take to sell..." (28-29). Although the description is of events that took place in the past, the use of the present tense brings the reminiscence to life again, and depicts them as more immediate, more real. Hughes' decision to follow the established tradition of using the preterite as the tense of narration results in a distancing of the reader from the events in the novel. A similar divergence is found in the exchange between Bienaimé and Jean-Jacques (22/32). Once again, rather than having the impression that the scene is unfolding as he reads, the reader is slightly distanced from the action. This is the result of the "free indirect speech" of the original - Bienaimé's stream of consciousness - being translated into "direct speech" : the presence of the narrator intrudes upon the relationship between the character and the reader.

As the novel progresses, however, Hughes does begin to make use of "free indirect speech" as well as the present tense in his descriptions. Examples are found in the narrator's commentary regarding Délira's mournful 
singing: "Life has taught black women to sing as though they are choking back a sob, and it's a song that ends always with a beginning because it's in the image of misery. And does the circle of misery ever end?" (102), as well as in the following interjection: "Rage almost strangled Hilarion. Ah, you can imagine how furious he became," (185). And finally, the involvement of the narrator is clear in the following presentation of day's dawning in FondsRouge:

It's like that in every yard. Thus day begins, with a light that can't make up its own mind, drowsy trees, and smoke rising behind the huts - for it's coffee time. And it isn't a bad idea to dip a piece of cracker in it if the coffee is well sweetened - with cane syrup, of course, because sugar, even brown sugar, the cheap kind, simply can't be had these days. (119)

Given the striking difference in impact between these last examples and earlier examples of the impersonal descriptive passages where the preterite is used, it is surprising that Hughes did not opt to make use of this writing style more widely as it is in the original text. Because Roumain's emphasis on "free indirect speech" is fundamental to the overall tone of the novel, making it come alive for the reader, Hughes might have better conveyed this quality in his translation through a more adventuresome narrative style. As is evident in the previous examples, a broader use of indirect discourse and of the present tense as opposed to the preterite results in a greater involvement of the reader as he or she has the impression of being addressed directly and drawn into the events of the story. In addition, even as Hughes retains more indirect discourse, his tendency remains to clearly 
delineate dialogue from description, while Roumain's blending of the two gives his novel a more fluid quality.

\section{Foreign Words}

Foreign words in a text pose the problem of "double translation, or translation at one remove" (Lefevere, 29). As Lefevere points out, to "regularize" the foreign words - that is, to find some English equivalent for the Spanish or creole terms - would sacrifice the flavor of the original text, whereas not providing a translation may frustrate the target language reader who, perhaps having no associations with the culture from which the foreign word originates, is denied the image or impact intended by the author.

The language of Roumain's novel is a mixture of French, Haitian creole and Spanish, and his use of these languages is fundamental not only to the flavor, but also to the message of the novel. For instance, upon his return from Cuba, the protagonist's speech is dotted with Spanish terms and expressions which underscore the length of his sojourn in Cuba as well as the foreignness of the new ideas that he brings back with him. In particular, he uses the term "huelga" because there is no creole term for "strike." As Dash explains: "The notion of a strike is part of the Cuban experience and does not belong in the Haitian context. Consequently, there is no creole word for 'strike' and Manuel is forced to explain the meaning of the Spanish word. To this extent language edits the world and presents a people's perception of reality" (19).

Because Hughes' primary objectives were for "authenticity and accessibility" (Dash, 18) he aims for balance by retaining certain terms and translating others. While Roumain uses Spanish terms and expressions and 
gives their translations in footnotes, Hughes chooses to translate the majority of them: "Hé, qué pasa?" (31), as "'Hey! What's the matter?' he exclaimed in Spanish" (39); "Adieu, compadre" (44) as "Adieu, friend" (51); and "Vamos" (63) as "Let's go see..." (68), all of which diminish the intended impact of the original. Perhaps the clearest example of this loss of impact is found in "'You damned Haitian! You black hunk of dung!' the police howled in Spanish" (43) as opposed to "Haitiano maldito, negro de mierda" (34). Because the power of the Spanish curse is weakened in the "gentler" English translation, Hughes would have better succeeded in retaining the tone of the original work by keeping the Spanish expressions with footnoted translations. Another important term, "huelga," mentioned above, is translated by Hughes without reference to the Spanish, so the fact that to go on strike was a foreign concept that Manuel was describing to his people is lost in the English translation.

The fact that Manuel's speech was peppered with Spanish terms is only suggested in the English through the use of "tags" such as "...he exclaimed in Spanish" (39) and the commentary on Annaïse's perception of Manuel's speech: "...she was completely absorbed in this somber voice that hit each sentence hard, and sometimes threw in the magnificence of a foreign word" (38). However, because the only non-English word used by Manuel in this section is the French "oui" that Annaise uses also, the reader is left to wonder what these foreign words might be.

In one important instance - when Manuel is describing the conditions of the workers in Cuba - Hughes does keep the Spanish: "Matar a un Hatiano o a un perro: to kill a Haitian or a dog is one and the same thing, say the rural police" (50). As in the original text, the use of the Spanish lends 
credibility to Manuel's experience in Cuba and emphasizes the brutality of the local police.

As for the creole terms in the original text, most are translated into English: "mabouya" (lizard) and "maringouin" (mosquito), for example, but a few Hughes chooses to keep, such as "coumbite," the agricultural workers' collective (25), "clairin," sugar cane alcohol (43), and "houngan," a voodoo priest (64). These terms Dash describes as "essentially untranslatable creole words" (20), or, in the words of Lefevere, "culture-bound words" (82). Because no equivalent or obvious analogy for the concepts that they represent exist in the target culture, the best solution is to retain the original term and define it either through its context, in a footnote, or, as in the case of the previously cited examples, in a glossary of terms at the end of the novel.

In other instances, however, Hughes abandons the creole altogether where maintaining the creole with annotation would have better kept the flavor of the original work. These include the majority of the creole sayings and songs which fundamentally embody aspects of the Haitian culture. A prime example is the saying: "Pissé qui gaillé, pas cumin (Le pissat dispersé n'écume pas)" (38) which Hughes renders as "'Urine that spreads don't foam'" (46). While the grammatical error "don't" conveys the slang of the expression, the more vulgar term suggested by "pissé" is forsaken in the choice of "urine." Likewise, the chants of the coumbites, the most important symbol of the Haitian peasants' ideal existence: living in harmony with each other as well as with the earth, are given only in English (15-16) (27-28). Finally, the day of Manuel's return, Délira, overcome with emotion, greets him with the terms of endearment that a mother would use with her son who has been away for fifteen years, namely in creole as she would have 
addressed him as a small child: "Pitite mouin, ay pitite mouin" (32). Hughes, however, translates her exclamation into English: "My baby! Oh, my baby!" (40) which, while it does incorporate the important elements of possession ("my") and small one ("baby"), eliminates the change in tone associated with the change in language: French being the more formal language, creole the more personal and intimate.

In his article entitled "Some Problems of Style in Translation from French," L.W. Tancock asserts that "tone in dialogue is perhaps the most severe test of a translator's ear, for... meaning, fidelity to cultural background and national characteristics, period, character, emotional pitch and so on... show up most clearly in dialogue" (46). Here, Hughes keeps the "foreign" flavor of the original text primarily through the use of French. In particular, he preserves the frequently repeated salutations: "oui" (cf. 36, 41); "bonjour" (cf. 38, 42); and "au revoir" (cf. 39). The difficulty as defined by Tancock, however, is also occasionally evident in Hughes' translation: for some expressions - "pet names" in particular - cultural differences compound differences in language, and appropriate English expressions are hard to find.

Perhaps the single most difficult expression to translate consistently into English is the term "nègre." As Laroche explains, Roumain uses the French for the most part as a synonym for the creole "neg": "Pour dire homme la langue haitienne dispose du mot «neg». Jules Faine nous dit qu'en créole haïtien «le mot nègre désigne l'homme en général sans acceptation de race.»...." (283). In addition, he explains that an analysis of Roumain's use of the term reveals the "conflit des langues comme révélateur d'un conflit des idéologies et donc du combat social dans le champ symbolique" (266). A discussion of the "diglossia" of Haiti and its social and political 
implications is a topic deserving thorough investigation (cf. Bebel-Gisler, Dejean, Sylvain) - here, however, the goal is to determine the intended meaning of "nègre" in order to assess the accuracy of its translation. As defined above, "nègre" means "man" in general. It is often used in expressions of endearment and respect among natives, and it has neither derogatory connotations nor English equivalent. As for its translation, the American argot "nigger" is not an option because of its strongly negative associations. By the same token, Hughes chooses to use on occasion the dated and somewhat stilted expression "Negro," which creates "...a very odd situation when it is used by the peasants" (Dash, 20). Examples include, "'But may the lightning cut me in two if you aren't a fine looking Negro! [sic]"' (46), and "'You're a persistent Negro!"' (53). Perhaps Hughes' intention was to emphasize the Spanish and Portuguese "negro"="black" root of the term, but because of the negative connotations that the term evokes for an American reader, a more favorable solution would be either to keep the original creole (a definition for which Hughes provides in the glossary), or find another English term (Dash suggests "man" or "brother," [20]) appropriate for the situation in which "nègre" is used. As an adjective, "nègre" is translated as "black": "Et sûrement qu'il y a des anges nègres pour faire le gros travail..." (36) = "Of course, they have black angels to do the heavy work..." (45). Interestingly, Hughes retains the feminine form "Négresse" - capitalized, as with "Negro" - in almost all instances (i.e. 28, 30 ), and includes a thorough and accurate definition in the glossary.

Another expression which presents difficulties for translation is "compère" along with the feminine form "commère." Hughes' translation of "commère" (22) into "Sister" (32), though not literal, transmits effectively the 
feeling and attitude of the expression: friendship, tenderness, and relational ties. The term "compère" (14) on the other hand, is translated into the adjectival "wise old" (25) which retains the element of respect, but loses the sense of closeness. Another example of this loss of alliance is the translation of "beau-frère" (37), suggesting a familial relation, as "pal" (45), implying only friendship. A similar diminution occurs in the translation of "nègre $\grave{a}$ moué" (12) into "Oh honey" (24) which loses the quality of possession - "à $m o i "$ - that the alternatives "My honey" or "My dear" would have maintained.

On the other hand, the two expressions "mon nègre" (22) and "mon cher" (20) are translated as "old man." Both of the French expressions are found in exchanges between male friends, and the English solution succeeds in transferring the sense for the target audience because of the frequent use and positive connotations of "man." However, "old man" as the translation of the term "maudit" (12) is somewhat less effective: because it is a curse in French, an expression such as "damn you" would have better captured the anger and frustration that the character is voicing.

\section{$\underline{\text { Neologism }}$}

"Sometimes writers invent new words to strengthen the illocutionary power of their texts" (Lefevere, 41). The building blocks for these new words are existing words, or parts of words, whose connotations or sounds infuse the new word with meaning. As mentioned in Chapter III, if choosing to translate rather than omit a neologism, the translator must assess the illocutionary power of the word or elements of the word and create a comparable neologism in the target language. 
In the case of Gouverneurs de la rosée, for example, the term "le télégueule" (129) represents the transmission of information by word of mouth - so efficiently executed that it is accomplished as by a machine. Hughes' solution to this neologism is "the tell-a-mouth" (129) which succeeds through the use of "tell-a" which sounds like "tele-" as in "telephone" and also conveys the sense of transmission of information. The element that is missing, however, is the vulgar "gueule" which implies the mouth of an animal. Unfortunately, English lacks a comparable term (other than perhaps "jowl"), so "mouth" is the best choice.

Roumain also creates "l'avalasse" to complete the following "trinity" sent from the heavens: "...le ciel noir s'ouvrait pour l'averse, l'avalanche, l'avalasse torrentielle" (21). In this case, however, Hughes chooses to omit the neologism: "...the black heavens had opened in an avalanche, a torrential deluge" (31). Were Hughes committed to creating an English counterpart for "avalasse," however, he could have considered the elements of the term, "avalanche" + "-asse" (a pejorative noun or adjective ending) and come up with "avalesque" as a possible solution.

\section{$\underline{\text { Register }}$}

Decisions as to the choice of words used in a translation must always be made with the social and cultural situation of the original text in mind. As Lefevere points out, language never occurs in a vacuum - certain words and expressions are "appropriate" for certain situations, and authors "can exploit all kinds of discrepancies between utterance (the use of language) and situation (the particular context in which language is used) to heighten the 
illocutionary power of their texts" (58). An example is the character Antoine's use of his "français français, " his "frenchest French":

"Mademoiselle, depuis que jé vous ai vur, sous la galérie du presbytè, j'ai un transpố d'amou' pou' toi. J'ai déjà coupé gaules, poteaux et paille pou' bâtir cette maison de vous. Le jou de not' mariage les rats sortiront de leurs ratines et les cabris de Sor Minnaine viendront beugler devant notre porte. Aló pou' assurer not' franchise d'amour, Mademoiselle, je demande la permission pour une petite effronterie. " (41)

The sharp contrast in this passage between the standard French "Mademoiselle" and "je demande la permission pour une petite effronterie" with the vulgar "beugler" along with his "mispronunciations": "vur," "pou'," "Alô," and "not"" emphasize the humor in Antoine's proposition. Hughes' translation produces similar effects through the use of grammatical errors "...since I seen you..., I had a passion of love for you," in contrast with a more formal language as evidenced by the proper "Mademoiselle," and "I ask your permission for a little effrontery" (49).

By the same token, however, unintentional "clashes" of utterance and situation can have a jarring effect, and either "stiffen" a language which should be casual or familiarize what should be formal speech. Hughes' choice of "Negro" as the translation for the creole "nègre" is one such example: the English expression is dated and certainly does not have the French term's "connotation of affection, entirely non-racial in meaning" as Hughes himself explains in his glossary. Today, the common black expression "brother" which implies closeness as in "one who is like me" would provide a much more effective alternative. 
Another example is found in Hughes' translation of the creole saying: "Pissé qui gaillé, pas cumin (Le pissat dispersé n'écume pas)" (38) which has the same implication as "A rolling stone gathers no moss." Hughes' solution is "Urine that spreads don't foam" (46): while the grammatical error "don't" captures the slangy nature of the expression, the proper "urine" sounds too formal. Perhaps Hughes was afraid to offend his audience by using the crude but much more à propos "piss." Were this the case, however, he probably would not have chosen to use "the bitch" (185) as the translation for "la salope" (189): curses were apparently not entirely out of the question in his opinion.

Finally, Hughes uses the quite stilted adjective "droll" (37) to describe the awkward little jumps that Manuel make to try to regain his balance after stumbling: "...quelques petits bonds assez ridicules" (28), and similarly, Délira's exclamation "Ah, bah!" is translated as "Oh, fiddlesticks!" (183).

\section{Syntax, Grammar}

Laroche writes of the evolution in Haitian literature from works written entirely in French (1804-1900) to a "texte diglottique en franco-haïtien" (1900-1950), and finally to a uniquely Haitian literature (263). Included in the second category, Gouverneurs de la rosée reveals the blending of the two languages.

In his introduction, Dash underlines Roumain's creative use of language:

In order to be faithful to the peasant experience in his novel, Roumain had to create a language that was based on creole but was accessible to a wide French-speaking public. It is 
interesting to note that Roumain did not resort to slangy French or broken French in order to convey the characteristics of peasant speech. (19)

Rather, Roumain interjects creole terms, sayings, and songs, and modifies the rhythm and word order of his characters' speech to give their French the feel of the Haitian creole language. For example: "Délira, cousine, adieu, oui, Bienaimé, frère, adieu, oui" (44), and "Quel est ce grand causer que tu avais à me faire et comment, moi, Annaïse, je voudrais bien savoir, je pouvais aider un homme comme toi?" (83). Hughes keeps the syntax: "Délira, cousin, adieu, oui. Bienaimé, brother, adieu, oui" (51). Hughes also occasionally slips into the "vernacular of the South" (Dash, 24) giving the characters' speech an easy, more casual feel: "There's a hateful dog for you, a dog that don't like anybody" (52). Dash gives the example of "the earth's bad off" (24), and suggests that these "...seem to approach what Roumain attempted in the original" (21). 


\section{CHAPTER VI}

\section{MASTERS OF THE DEW: \\ POETIC LANGUAGE}

"Literature is a highly redundant type of message, saying the same thing simultaneously at many different levels: denotation, connotation, form, rythms and sounds all converge to form a unified whole...[sic]" (di Stefano, 254). It is these elements in particular - the "poetic language" of Gouverneurs de la rosée - which make the novel so extraordinarily expressive and so difficult to translate. As Guillaume asserts: "The pitfalls of poetic language can be dangerous even to the most accomplished translators, and certainly to an amateur translator like Hughes..." (3).

\section{FEATURES OF HUGHES' TEXT}

\section{Alliteration, Assonance and Rhythm}

As mentioned previously, Roumain's writing is rich with rhythm which is a product primarily of the repetition of initial consonant sounds (alliteration), consonant or vowel sounds within words (assonance), and of entire words or phrases. For example, note the recurring $/ \mathrm{k} /$ sound in "couper la canne à sucre à Cuba" (23). The harshness of the sound underscores the brutality of the work involved (Délira assumes that the work must have killed Manuel by now: "Il doit être mort maintenant,"). The impact of this trope 
was not lost on Hughes who retained the alliteration in this case: "to cut cane in Cuba" (32), even leaving out the qualifier "sugar" to strengthen the impact by reducing the number of other sounds interfering.

Roumain also employs assonance, as in: "Un éclair de lumière en frappant le fer..." (15). In this case, the /عr/ sound both unites and gives a rhythm to the phrase which adds to the beauty of the image that Roumain creates. (He continues: "ils brandissaient, une seconde, un arc de soleil" [15]). Hughes apparently saw no obvious English counterpart: "A beam of light would strike each blade. For a second they would be holding a rainbow" (26). On occasion Hughes does add alliteration to compensate for the many instances - as with the previous example - in which he leaves them out: "...a hot haze distorted the half-hidden silhouette of far-off mountains" (24).

\section{Metaphor}

As Newmark says, good writers "use metaphors to help the reader to gain a more accurate insight, both physical and emotional, into say a character or a situation" (Newmark, 93). Jacques Roumain's writing is rich with metaphors which serve to bring to life both the physical and spiritual worlds of the Haitian people whose story he tells. In the words of Newmark, metaphor serves "as an attempt to cerner, delimit, define an object or process, physical or mental, more closely;... [and] ... as an attempt to produce emotive effect" (100). The translation of metaphor can often pose problems. Mason asserts, however, that "all language requires the translation of man into language, and language... is the metaphor by which man expresses himself. Therefore all language is metaphorical in its origin... Any problems we may have when encountering a metaphor are located at the level of 
interpretation" (141). Newmark concurs: "...all symbols are metaphors or metonyms replacing their objects, all words are therefore metaphorical" (93). Metaphor is technically no more or less difficult than any other type of language to translate, according to Mason, "...it is just that metaphor brings these problems to the surface, as it were, of the quagmire of cultural context in which all words wallow" (Mason, 141).

This fact, however, particularly when translating between two quite disparate cultures, is no small detail. The translator must first analyze the meaning and assess the impact of the metaphor in the source language text, then determine if a metaphor with similar meaning and impact can be created in the target language and appreciated by the target audience. The point is made by Newmark that it is essential that the translator "assess the status of the metaphor before he translates" (100) - he must "have a discriminating sense of priority, to carefully distinguish major and minor factors/components/parameters in each text" (94). It is here that Hughes sometimes misses. It is the "emotive effect" of the metaphor to which the translator must pay particular attention, and he must determine how the emotional impact of the image can be transferred to the target language reader.

As outlined in the biographies of Jacques Roumain and Langston Hughes, the latter's qualifications as poet and social activist keenly aware of the political and social situations of Haiti presumably made him the translator best equipped for the task of recreating Roumain's novel for an American, English-speaking audience. It is therefore surprising to note certain few but important omissions in Hughes' translation which are fundamental elements of the original work. For example, in the lengthy reminiscence of the "good old 
days" of the "coumbites," the narrator/ Bienaimé describes the action as "On entrait dans l'herbe de Guinée!" (14) which Hughes translates as "Into the field of wild grass they went" (24). In addition to the "on / they" distinction discussed earlier, Hughes loses the powerful metaphor for the Haitians' sense of "paradise lost": in Haitian folklore, it is believed that the souls of the dead return to Guinea, the mythical country of their ancestors, to be reunited with the souls of their ancestors and live in harmony. This reference to the "grass of Guinea" rather than the "wild grass" embodies - in addition to the image of the lushness and fertility of the land - the allusion to the past as having been a paradise where they lived in peace and harmony. While the reason for the omission may have been the lack of familiarity of the target audience with the beliefs of the source culture, the significance of the metaphor merits its retention and elucidation in a footnote. The translator might also have referenced a later passage describing the belief in the dead returning to Guinea which he has retained (34/42) and (63/68).

For the most part, Hughes translates "faithfully" Roumain's anthropomorphisms of the earth and, in this respect, his translation captures much of the tone of the original work. For example, upon his return to FondsRouge, Manuel reminisces about the trees and other greenery with which the village had once been adorned, but now "...all that, the sun had licked up, effaced with a single stroke of its fiery tongue" (36). This image emphasizes the rapidity and completeness with which the once fertile land had been transformed to parched earth.

There are a few instances, however, where Hughes has chosen to omit certain instrumental passages. An example of the exclusion of a rich metaphoric passage from which readers unfamiliar with Haitian culture would 
have obtained a better understanding of the peasants' bond with the earth is that of the following paragraph:

Si l'on est d'un pays, si l'on y est né, comme qui dirait : natif-natal, eh bien, on l'a dans les yeux, la peau, les mains, avec la chevelure de ses arbres, la chair de sa terre, les os de ses pierres, le sang de ses rivières, son ciel, sa saveur, ses hommes et ses femmes: c'est une présence, dans le cour, ineffaçable, comme une fille qu'on aime : on connaît la source de son regard, le fruit de sa bouche, les collines de ses seins, ses mains qui se défendent et se rendent, ses genoux sans mystères, sa force et sa faiblesse, sa voix et son silence. (26)

As Mason emphasizes, "...any metaphors that occur in the text must be interpreted within the context of the whole text and translated accordingly" (142). This metaphor of the earth as a human body underscores the Haitian peasant's oneness with nature, and its omission denies the reader of the translation this understanding and appreciation. Again, Mason points out that the translator is continually faced with the decision "...to allow the SL culture to remain dominant in the TL text, or whether he wants to produce a version of the SL text as such a text, with that kind of plot, etc, might have been written in the TL,": in choosing the latter option, however, the "...TL readers [are] deprived of much information of great value about the SL culture" (145).

Finally, the overtly sexual nature of the following paragraph undoubtedly led to its demise:

Travaillé durement en nègres conséquents, en travailleurs de la terre qui savent qu'ils ne pourront porter un morceau à la bouche s'ils ne l'ont extrait du sol par un labeur viril. Et la terre avait répondu : c'est comme une femme qui d'abord se 
débat, mais la force de l'homme, c'est la justice, alors, elle dit: prends ton plaisir...

Were Hughes' decisions to omit these passages based on the perceived necessity to keep his translation to a certain length, perhaps as prescribed by the publishing house, or - especially in the case of the second and third excerpts - because of a sensitivity to the response of the target audience to the overtly sexual nature of the passages? The latter reason was not the case, however, with the scene in which Manuel and Annaïse are making love: "Beneath his touch, her body burned. He unlocked her knees, and she opened herself to him. He entered, a lacerating presence, and she gave an injured groan," etc. (118) Perhaps Hughes was concerned that the third passage in particular, with its metaphor for the working of the earth as rape, would have offended his target audience, branded the work as a whole as obscene, and therefore jeopardized its success. As Lefevere acknowledges:

Translators are interested in getting their work published. This will be accomplished much more easily if it is not in conflict with standards for acceptable behavior in the target culture: with that culture's ideology. If the source text clashes with the ideology of the target culture, translators may have to adapt the text so that the offending passages are either severely modified or left out altogether. (87)

The final image in Roumain's novel is that of the water at last streaming into the area. Roumain uses the image of the blade of a knife reflecting the sun: "Une mince lame d'argent s'avançait dans la plaine..." (192), and the reader is left to wonder if this fulfillment of a dream and so many prayers 
might not be "double-edged." While it provides the much-needed nourishment for the earth, will it be a divisive force as the inhabitants struggle for its control, or will the teachings and influence of Manuel survive? This concern is foreshadowed in the thoughts of Hilarion as he considers the potential for taxing the water rights, and wonders if Manuel will continue to lead them after his death (189). Because Hughes chooses to omit this metaphor, the implied uncertainty and warning for the future are lost.

\section{"Double entendre"}

The lyric poetry of the fifteenth century French poet François Villon is in the twentieth century more fully appreciated for the layers of meaning it comprises. Fein writes of the two readers for whom Villon writes: the "privileged reader" and the "anonymous reader." He explains:

The passages directed to the privileged reader are sharply focused on the reader, in the sense that they rely on him to flesh out images, interpret tones, discern ironic meanings, supply pertinent information, decode hidden messages, and continually read the text against his personal knowledge of the author. The passages directed to the anonymous reader... are those whose comprehension does not require highly specific knowledge on the part of a particular reader. (99)

The nature of this writing is often politically subversive (as in the writings of Voltaire), or implies the discussion of a socially "taboo" subject such as sex. For example, the native French speaker reading Roumain's novel may see the creole term for the agricultural worker's group, coumbite, as being derived from the old French "combe" meaning "deep valley," and the 
slang "bite" meaning penis, and thus denoting the male workers who go out into the fields to work.

Indeed, much of Roumain's writing has meaning on many levels. Consider, for example, the title of his novel. As pointed out by Dash, "Gouverneurs de la rosée" "suggests three levels on which the novel was conceived" (13). The expression denotes a specifically Haitian peasant experience because it is from the Haitian creole and signifies those who oversee the watering of the fields. On another level, it implies the Marxist concept of "man as master of his own fate, imposing his will on the world," and finally, a "lyrical and poetic resonance to the experience described, suggesting behind the message a universal kind of allegory" is ascribed to Roumain's choice of the term "dew" rather than "water" (Dash, 13).

In a similar manner, the sexual is reflected in nature to emphasize the life-giving, positive force of the earth. In the following descriptive passage, for example, several aspects of the functions of the tree suggest human sexuality:

Un arbre, c'est fait pour vivre en paix dans la couleur du jour et l'amitié du soleil, du vent, de la pluie. Ses racines s'enfoncent dans la fermentation grasse de la terre, aspirant les sucs élémentaires, les jus fortifiants. Il semble toujours perdu dans un grand rêve tranquille. L'obscure montée de la sève le fait gémir dans les chaudes après-midi. C'est un être vivant qui connaît la course des nuages et pressent les orages, parce qu'il est plein de nids d'oiseaux. (18)

This paragraph lauds the vitality of the tree - frequently recognized as the universal symbol of life and harmony - incorporating the basic elements of 
fire (sun), air (wind) and water (rain), as well as uniting the ground, into which its roots penetrate and from which it draws succor, and the sky, knowing the course of the clouds. Notable in particular is the second to the last sentence which strongly suggest the stirring of sexual desire "on hot afternoons." This sublimation of earthly pleasure lauds the fertility rite, birth and the beauty of the life-giving process in general.

The significance of this passage is further underscored in the original text by its contrast with the expression of death in the paragraph which follows, and which describes what becomes of such noble and beautiful trees in the quest for charcoal (one of the few remaining sources of income for the peasants): a charred skeleton in a pile of ashes: "De l'arbre mutilé, il ne reste que le squelette calciné des branchages épars dans la cendre : une charge de charbon que sa femme ira vendre au bourg de la Croix-des-Bouquets" (18). By omitting this metaphor of the tree as a living, life-giving, prophetic entity, the reader is denied not only the full impact of the tragedy of its rampant destruction, but also further insight into the beliefs and world view of the Haitian people: in particular their spirituality which is so intimately rooted in the earth.

On another occasion, Roumain parallels the relationship between man and wife with man and the earth. After his lengthy reminiscence of the days of the coumbites when the land was fruitful, Bienaimé first remembers his wife, then comments that, in the "good old days": "Voilà ce que c'était de vivre en bon ménage avec la terre" (22). Hughes' translation of this expression as "...living on good terms with the earth..." (32) does not incorporate the intimacy implied by the use of the term "ménage" - implying couple, household, family - in the original. 
Images of sex and sexuality abound in Roumain's novel, and the author succeeds in portraying the Haitian's acceptance of the sexual as positive, natural, and even beautiful as opposed to wrong and taboo. In his translation, Hughes sidesteps by omitting several of the sexual references in the original text. Once again, his readers are denied understanding an important quality of the culture about which Roumain wrote. 


\section{CHAPTER VII}

\section{CONCLUSION}

The research and exercise in comparative literature represented in this paper have been instructive on many levels. In the first place, the subjectivity of translation has been underscored. While there unquestionably exist cases in which the assessment of a particular translation as "right" or "wrong" is relevant and useful - as in language learning exercises, for example - literary translation, because it is based on and is the expression of literary interpretation, will always be subjective to a degree because an individual's perspective is shaped by his specific culture, background and beliefs. In addition to the qualities that the translator himself brings to the project, his work is also quite likely to be influenced by external factors such as the realm of "acceptable" expression as defined by the target audience, as well as the restraints or expectations of the publishing house with which he is working.

In light of the previous points and in spite of the criticisms that have been made in the previous chapters of Masters of the dew, it is my opinion that this translation was largely successful in making the original text - its world and message - available to the target audience for which Hughes and Cook were translating. Again, this exercise was undertaken not to belittle the significant accomplishment of the translators, but in the interest of highlighting some of the difficulties that their project entailed. 
Examples in Chapter $\mathrm{V}$ of this work show that the language of Langston Hughes' and Mercer Cook's translation of Jacques Roumain's novel is, in the eyes of today's reader, "dated." For example, if this novel were to be translated today for an American target audience which has become much more multi-cultural, it is likely that more of the Spanish terms would be retained. Exposure to the language has greatly increased in the United States during the last fifty years due to a great increase in the Hispanic population, and therefore more Spanish expressions are familiar to a larger segment of the American population. Also, because the status of African Americans in our society has changed radically in the last fifty years, more of the language of their culture has become "mainstream," so that terms such as "brother" or "man" are more widely used and familiar. Moreover, we have become "desensitized" to many of the curses that Hughes chose to omit from his translation: they would be considered "acceptable" in a work of literature written today. And finally, today's translator may be more likely to try to recreate the structure of Roumain's novel, adopting a more adventurous narrative style.

Perhaps the previous hypotheses are feasible because, as a society, we are broadening our definition of "acceptable" as well as our appreciation for what is of artistic value. We are moving towards the embracing of difference and originality as opposed to the striving for some abstract perfection as defined by one particular majority.

To this end, the importance of and the value in moving away from the critique of translation based on the traditional dichotomies of "right" versus "wrong" and "good" versus "bad" have been acknowledged. This exercise, however, has also highlighted the fact that habit is difficult to break. Any 
interpretation - whether of an original text or of a translation - is necessarily subjective, and our tendency is to pass judgment when we agree or disagree with another's choice.

The current controversy surrounding the interpretation and translation of the Dead Sea Scrolls shows us that no interpretation is ever definitive, and how significantly the mis-translation of one word can impact the meaning and the reception of the translation (cf. Altman). Because Langston Hughes worked from an initial translation done by Mercer Cook, an interesting study would be to compare Cook's original translation with both Roumain's and Hughes' novels to identify if and how this intermediary, "hub" text may have influenced Hughes' decisions to "stray" from the original work.

Finally, while the astounding advances in machine translation technology have underscored the contributions of linguistics based theories of translation (cf. Hillenbrand; Nagao), the persistent obstacles to its complete success have made clear that no hard and fast rules governing literary translation are feasible. The human element will always be necessary: translation involves intuition and empathy for the subtleties of the intangible such as metaphor, satire and sarcasm. In the words of B. Follkart di Stefano: "Literary translation should be a critical reading of the text, that is, an analysis and, inevitably, an interpretation, but also a jouissance, a revelling in the text [sic]" (254). Translation involves both science and art; both linguistics and creative intuition / inspiration. 


\section{WORKS CONSULTED}

Altman, Neil. "Scrolls swirling in controversy." The Oregonian 13 March 1993: C1 \& C6.

Amos, Flora Ross. Early Theories of Translation. Folcroft, PA: The Writer, 1920.

Arrowsmith, William, and Roger Shattuck, eds. The Craft and Context of Translation. Austin: University of Texas Press, 1961.

Bar-Hillel, Yehoshua. Language and Information: Selected Essays on their Theory and Application. Reading, MA: Addison-Wesley Publishing Co., 1964.

Beaugrande, Robert Alain de. Factors in a Theory of Poetic Translating. Assen: Van Gorcum, 1978.

Bebel-Gisler, Dany. La langue créole force jugulée. Paris: L'Harmattan, 1976.

Berman, Antoine. "De la translation à la traduction." Traduction. Terminologie, Rédaction. 1988. 23-40.

Berry, Faith. Langston Hughes: Before and Beyond Harlem. Westport, CT: Lawrence Hill \& Co., 1983.

Betts, Jane Colville. "Arabian Nights." The New Grolier Electronic Encyclopedia (TM). $1991 \mathrm{ed}$.

Bloomfield, Leonard. Language. New York: Henry Holt \& Co., Inc., 1933. 
Bostick, Herman F. "From Romanticism to Militant Optimism: The Poetic Quest of Jacques Roumain." The Langston Hughes Review. 1983. 6-14.

Brower, Reuben A. (ed.) On Translation. Cambridge, MA: Harvard University Press, 1959.

Cary, Edmond. "Théories soviétiques de la traduction." Babel: International Journal of Translation. 1957. 179-90.

Catford, J. C. A Linguistic Theory of Translation. London: Oxford University Press, 1965.

Caws, Mary Ann. Introduction. Mad Love by André Breton. University of Nebraska, 1987.

"Children's Literature." The New Grolier Electronic Encyclopedia (TM). 1991 ed.

Dash, J. Michael. Introduction. Masters of the Dew. London: Heinemann, 1944. 5-21.

Dejean, Yves. "Diglossia revisited: French and Creole in Haiti." Word. 1983. 189-213.

Dickinson, Donald C. A Bio-bibliography of Langston Hughes. Hamden, CT: Archon Books, 1972.

di Stefano, B. Follkart. "Translation as Literary Criticism." Meta. 1982. 241-56.

Dubuc, Robert. "Problèmes et solutions: à l'écoute de la langue vivante." Meta. 1980. 249-53.

Espinola, Judith C. "The Nature, Function, and Performance of Indirect Discourse in Prose Fiction." Speech Monographs. 1974. 193-204. 
Fein, David A. François Villon and his Reader. Detroit: Wayne State University Press, 1989.

Fielden, Kate. "Cuneiform." The New Grolier Electronic Encyclopedia (TM). $1991 \mathrm{ed}$.

Forster, Leonard. "Translation: An Introduction." Aspects of Translation. University College London. London: Secker and Warburg, 1958. $1-28$.

Fowler, Carolyn. "The Shared Vision of Langston Hughes and Jacques Roumain." Black American Literature Forum. 1981. 84-88.

Gookin, Dan \& Rathbone, Andy. PC's for Dummies. San Mateo, CA: IDG Books Worldwide, Inc. 1992.

Gouadec, Daniel. "Paramètres de l'évaluation des traductions." Meta. 1981. 99-116.

Greppen, John A.C. "Languages, Extinct." The New Grolier Electronic Encyclopedia (TM). $1991 \mathrm{ed}$.

Gress, Elsa. "The Art of Translating." The World of Translation.

Conference on Literary Translation. New York: P.E.N. American Center, 1971. 53-64.

Guillaume, Alfred J., Jr. "And Bid Him Translate: Langston Hughes' Translations of Poetry from French." The Langston Hughes Review. Providence, RI. 1985. 1-23.

Hillenbrand, Barry. "Trying to Decipher Babel: Japanese translating machines make languages less foreign." TIME 24 July 1989: 62.

Hodges, Carolyn E. "Introduction: Reflections on the Art of Literary Translation and the Legacy of Langston Hughes." The Langston Hughes Review. Providence, RI. 1985. vi-ix. 
House, J. Theoretical Aspects of Translation. (Master's Thesis). Toronto: University of Toronto, 1971. ERIC ED 200043.

Hughes, Langston \& Cook, Mercer, trans. Masters of the Dew. By Jacques Roumain. London: Heinemann, 1944.

Jones, Tom B. "Ashurbanipal, King of Assyria." The New Grolier Electronic Encyclopedia (TM). $1991 \mathrm{ed}$.

"Khayyam, Umar." Petit Larousse illustré. 1982 ed.

Laroche, Maximilien. "La diglossie littéraire dans Gouverneurs de la rosée: termes de couleur et conflit de langues." Études littéraires. 1980. 263-288.

Lefevere, André. Translating Literature: Practice and Theory in a Comparative Literature Context. New York: The Modern Language Association of America, 1992.

Locke, William N. \& Booth, A. Donald (ed). Machine Translation of Languages: Fourteen Essays. London: Chapman \& Hall, Ltd., 1955.

Lortholary, Bernard. "Linguistique structurale et théorie de la traduction." Babel: International Journal of Translation. 1979. 197-203.

Mason, Kirsten. "Metaphor and Translation." Babel: International Journal of Translation. 1982. 140-49.

Miccollo, Henri. "Concordances et irréductibilités dans Gouverneurs de la rosée de Jacques Roumain et Bon Dieu rit d'Edris St-Amand." Conjonction. 1984. 9-33.

"Montherlant, Henry Million de." Petit Larousse illustré. $1982 \mathrm{ed}$.

"Mother Goose." The New Grolier Electronic Encyclopedia (TM). 1991 ed. 
Mounin, Georges. Les problèmes théoriques de la traduction. Paris: Gallimard, 1963.

Nagao, Makoto. Machine Translation: How Far Can It Go?. Transl.

Norman D. Cook. Oxford: Oxford University Press, 1989.

Newmark, Peter. "The Translation of Metaphor." Babel: International Journal of Translation. 1980. 93-100.

Nida, Eugene A. "Theories of Translation." Traduction, Terminologie, Rédaction. 1991. 19-32.

------. Toward a Science of Translating. Leiden, Netherlands: E.J. Brill, 1964.

Nida, Eugene A., and Charles Taber. The Theory and Practice of Translation. Leiden, Netherlands: E.J. Brill, 1969.

Notice bibliographique. (N.B.) Gouverneurs de la rosée. Paris: Éditions Messidor, 1946. 7-10.

Ojo, Patchechole Poindexter. "Nature in Three Caribbean Novels." Journal of Caribbean Studies. 1981. 85-107.

Ormerod, Beverly. An Introduction to the French Caribbean Novel. London: Heinemann Educational Books Ltd, 1985.

Rabassa, Gregory. "The Ear in Translation." The World of Translation. Conference on Literary Translation. New York: P.E.N. American Center, 1971. 81-86.

Rampersand, Arnold. The Life of Langston Hughes, Volume II: 19411967, I Dream a World. New York: Oxford University Press, 1988.

Robinson, Douglas. The Translator's Turn. Baltimore: Johns Hopkins University Press, 1990. 
Roumain, Jacques. Gouverneurs de la Rosée. Paris: Éditions Messidor, 1946.

Saldarini, Anthony J. "Dead Sea Scrolls." The New Grolier Electronic Encyclopedia (TM). $1991 \mathrm{ed}$.

Schogt, Henri. "Analyse sémantique immanente, référence et traduction." Meta. 1981. 117-22.

Savory, Théodore. The Art of Translation. Boston: The Writer, 1968.

Souffrant, Claude. "Jacques Roumain et Anthony Phelps: Le christianisme haïtien de libération." Conjonction. 1986. 46-51.

Sylvain, Suzanne. Le créole haitien: Morphologie et syntaxe. Genève: Slatkine, 1979.

Tancock, L.W. "Some Problems of Style in Translation from French." Aspects of Translation. University College London. London: Secker and Warburg, 1958. 29-51.

Vinay, J.-P. \& Darbelnet, J. Stylistique comparée du français et de l'anglais. Paris: Marcel Didier, 1958.

Yetiv, Isaac. "Gouverneurs de la rosée, une leçon d'humanisme." Conjonction. 1986. 55-58. 